\title{
Assessment of the Levels of Pollution and of Their Risks by Radioactivity and Trace Metals on Marine Edible Fish and Crustaceans at the Bay of Bengal (Chattogram, Bangladesh)
}

\author{
Krishna Prasad Biswas ${ }^{1}$, Shahadat Hossain 2,3 ${ }^{\mathbb{D}}$, Nipa Deb ${ }^{2}$, A.K.M. Saiful Islam Bhuian 2,*(D), \\ Sílvia C. Gonçalves ${ }^{4, * \mathbb{D}}$, Shahadat Hossain ${ }^{2}$ and Mohammad Belal Hossen ${ }^{1}$
}

1 Department of Physics, Chittagong University of Engineering and Technology, Chattogram 4349, Bangladesh; kpbcu@yahoo.com (K.P.B.); belalcuet@gmail.com (M.B.H.)

2 Atomic Energy Centre, Bangladesh Atomic Energy Commission, Chattogram 4209, Bangladesh; sahedmc@gmail.com (S.H.); nipaacdu@yahoo.com (N.D.); shahadat.baec@gmail.com (S.H.)

3 Interdisciplinary Graduate School of Engineering Sciences, Kyushu University, Fukuoka 816-8580, Japan

4 MARE-Marine and Environmental Sciences Centre, ESTM-School of Tourism and Maritime Technology, Polytechnic of Leiria, 2520-641 Peniche, Portugal

* Correspondence: saiful.bhuian@baec.gov.bd (A.S.I.B.); silvia.goncalves@ipleiria.pt (S.C.G.); Tel.: +88-0199-403-4539 (A.S.I.B.)

check for updates

Citation: Biswas, K.P.; Hossain, S.; Deb, N.; Bhuian, A.K.M.S.I.; Gonçalves, S.C.; Hossain, S.; Hossen, M.B. Assessment of the Levels of Pollution and of Their Risks by Radioactivity and Trace Metals on Marine Edible Fish and Crustaceans at the Bay of Bengal (Chattogram, Bangladesh). Environments 2021, 8, 13. https://doi.org/10.3390/ environments 8020013

Academic Editors: Claude Fortin and Vernon Hodge

Received: 10 November 2020

Accepted: 1 February 2021

Published: 11 February 2021

Publisher's Note: MDPI stays neutral with regard to jurisdictional claims in published maps and institutional affiliations.

Copyright: (c) 2021 by the authors. Licensee MDPI, Basel, Switzerland. This article is an open access article distributed under the terms and conditions of the Creative Commons Attribution (CC BY) license (https:/ / creativecommons.org/licenses/by/ $4.0 /)$.

\begin{abstract}
Marine environmental pollution is a longstanding global problem and has a particular impact on the Bay of Bengal. Effluent from different sources directly enters rivers of the region and eventually flows into the Bay of Bengal. This effluent may contain radioactive materials and trace metals and pose a serious threat to the coastal environment, in addition to aquatic ecosystems. Using gamma spectrometry and atomic absorption spectrometry, a comprehensive study was carried out on the radioactivity $\left({ }^{226} \mathrm{Ra},{ }^{232} \mathrm{Th},{ }^{40} \mathrm{~K}\right.$, and $\left.{ }^{137} \mathrm{Cs}\right)$ and trace metal $(\mathrm{Cd}, \mathrm{Pb}, \mathrm{Zn}, \mathrm{Cu}, \mathrm{Ni}, \mathrm{Fe}, \mathrm{Mn}$, and $\mathrm{Cr}$ ) concentrations, respectively, in fish and crustacean species collected from the coastal belt of the Bay of Bengal (Chattogram, Bangladesh). The analysis showed a noticeable increment in the levels of different radioactive pollutants in the marine samples, although the consumption of the studied fish and crustacean species should be considered safe for human health. Anthropogenic radionuclide $\left({ }^{137} \mathrm{Cs}\right)$ was not detected in any sample. Furthermore, the metal concentrations of a small number of trace elements $(\mathrm{Pb}, \mathrm{Cd}, \mathrm{Cr})$ were found to be higher in most of the samples, which indicates aquatic fauna are subject to pollution. The estimated daily intake (EDI), target hazard quotient (THQ), hazard index (HI), and target cancer risk (TR) were calculated and compared with the permissible safety limits. It was found that consuming the seafood from the Bay of Bengal may cause adverse health impacts if consumption and/or means of pollution are not controlled.
\end{abstract}

Keywords: radioactive materials; trace metals; bioaccumulation; marine fish; crustaceans; marine environmental pollution; Bay of Bengal

\section{Introduction}

The marine environment is one of the most important sources of life on Earth and performs a number of key environmental functions for the lives and livelihood of humans and other organisms. Marine environmental pollution is a longstanding global problem. Marine pollution affects the Bay of Bengal because of the vulnerability of its aquatic habitats to such pollution following the industrial revolution in the 19th century. Most aquatic ecosystems can cope with a certain degree of pollution, but severe pollution is reflected in changes in the fauna and flora of their communities [1]. Developing countries, including Bangladesh, are most affected by this human-made problem. Bangladesh is considered to be one of the most suitable countries for the Blue Economy following the recent establishment of a vast maritime boundary in the Bay of Bengal. The result of two verdicts on maritime boundaries, also involving Myanmar and India, allows Bangladesh to exclusively 
exercise its sovereign rights over $118,813 \mathrm{sq} \mathrm{km}$ of water. The affected area extends up to 12 nautical miles into territorial sea and includes a further Exclusive Economic Zone (EEZ) of 200 nautical miles [2]. However, agriculture runoff, untreated sewage, and industrial pollution are reportedly being discharged directly into rivers, eventually flowing into the Bay of Bengal. This effluent may contain radioactive materials and trace metals and pose a particularly serious threat to the coastal environment and the aquatic ecosystems $[3,4]$.

The main causes of radioactivity in the marine environment are seabed movement originating from underwater volcanic activity and undersea earthquakes, natural processes of weathering, and mineral recycling of terrestrial rocks [5]. Different types of geological materials and minerals, such as ores and igneous rocks, which often contain large concentrations of natural radioactive elements, contribute to the transfer of radionuclides to water through leaching action [3]. The level of naturally occurring radioactive elements in the marine environment has gradually increased due to human activities, such as mining and processing of ores, production of natural oil and gas, and combustion of fossil fuels in coal-fired power plants. Moreover, anthropogenic contributions are made by underwater nuclear device tests, post-nuclear disposal of industrial and radioactive waste, recycling of spent nuclear fuel, and accidents, including leaks from nuclear power plants [4-7]. Among the radionuclides, uranium, radium, and radon are soluble in seawater, whereas thorium is almost completely insoluble. These can dissolve in seawater and then attach to sediment on the seabed and suspended plankton in the seawater. These dissolved radionuclides and plankton, in the long run, contaminate marine organisms, including fish, crustaceans, and several types of shellfish [8].

In addition, trace metals are released into the environment from different sources, such as transportation, industrial activities, fossil fuels, agriculture, urbanization, and other human activities [6-9]. The release of large quantities of trace metals into nature has resulted in several environmental problems due to their non-biodegradability and persistence. Marine life can have a considerable aptitude for bioaccumulation and biosorption of trace metals [10-12]. Under certain environmental conditions, such as consolidated effects of biotic and abiotic factors, such as plants, animals, and microbes; the amount of sunlight in the ecosystem; the amount of oxygen and nutrients dissolved in the water; proximity to land; depth; and temperature; these trace metals may accumulate to a toxic concentration and cause ecological damage by threatening the health of aquatic and terrestrial organisms, including humans $[1,13,14]$. The principal pathway leading to human exposure to radionuclides and trace metals is the consumption of seafood. A large variety of seafood is eaten. Fish and crustacean species, because of their important dual role as both an integral element of marine food webs and a commercial food product for humans, are frequently selected as indicator organisms in studies related to pollution or the bioaccumulation processes of various noxious substances [15]. The bioaccumulation of trace metals and isotopic contaminants by the tissues and organs of marine organisms has been studied globally and has led to the adoption of the bioindicator concept for environmental quality assessments [5-8,16,17].

Research on the bioaccumulation of radionuclides and trace metals in the most commonly consumed fish and crustacean species in the Bay of Bengal region is limited. Given the importance of such knowledge, this study was carried out to determine the radioactivity and trace metal levels in six marine fish and four crustacean species of the northern coastal belt of the Bay of Bengal, Bangladesh. The bioaccumulation levels of radioactive materials $\left({ }^{226} \mathrm{Ra},{ }^{232} \mathrm{Th},{ }^{40} \mathrm{~K}\right.$, and $\left.{ }^{137} \mathrm{Cs}\right)$ and trace metals $(\mathrm{Cd}, \mathrm{Pb}, \mathrm{Zn}, \mathrm{Cu}, \mathrm{Ni}, \mathrm{Fe}, \mathrm{Mn}$, and $\mathrm{Cr}$ ) were estimated by gamma spectrometry and atomic absorption spectrometry, respectively. Different radiological and health-hazard parameters were also calculated to assess the marine environmental quality in this region concerning these pollutants, in addition to the health risks resulting from the consumption of the studied seafood. 


\section{Materials and Methods}

\subsection{Sample Collection and Preparation}

The studied field locations were openly accessible, and the organisms collected did not belong to any protected species, so permissions were not required at the time of collecting samples from the studied locations. The investigated fish and crustaceans were obtained from four fish/seafood markets of the northern coastal belt of the Bay of Bengal, Chattogram, Bangladesh (Figure 1), during the rainy (July) and autumn (September and October) seasons of 2017. Bangladesh is a country of six seasons (summer, rainy, fall, autumn, winter, and spring). The fish investigated in this study are mostly available in rainy and autumn seasons. Hence, we obtained our samples in these two seasons. The fish samples were obtained from fishing boats operating in the corresponding locations, while the crustacean samples were obtained from a local sea food market in Chattogram city. A total of 20 samples (10 samples from each season) were chosen for investigation. The studied organisms were six fish and four crustacean species, locally available and commercially important, i.e., Tenualosa ilisha (Ilish), Harpodon neherues (Lotia), Sillaginopsis panijus (Sundora Baila), Sardinella longiceps (Colombo), Trichiurus lepturus (Churi), and Konosirus punctatus (Shad) concerning the fish species, and Scylla serrata (mud crab), Portunus sanguinolentus (three-spot swimming crab), Hemigrapsus takanoi (Asian shore crab) and Penaeus semisulcatus (cat tiger shrimp) concerning the crustaceans.
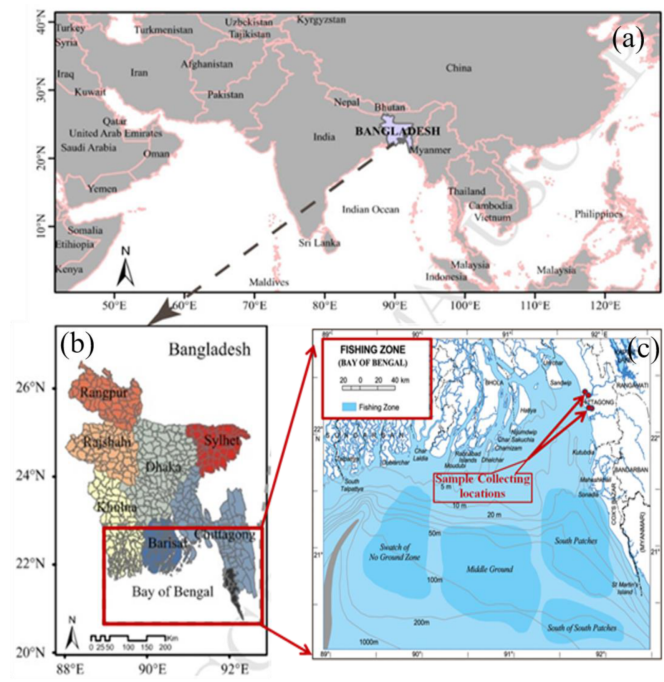

Figure 1. Location of the study area on the (a) world map, (b) Bangladesh map, and (c) Bay of Bengal map.

The details of the collected samples are given in Table 1. All the samples were labelled, stored in ice, and, on the same day, transported to the laboratory and washed with clean water and distilled water. Afterwards, the samples were dried in filter paper, packed in polyethylene bags, and stored in a refrigerator of the Laboratory of Atomic Energy Centre, Chattogram, to avoid degradation, spoiling, contamination, or any other decomposition until further treatment and analysis were done. The collected fish and crustacean samples were measured for the total wet weight (WW) and recorded beforehand. For the analysis of radionuclides and trace metal concentrations, all the animals were used in their entirety, since the analysis was intended to quantify the radioactivity and the metal concentrations of each organism. 
Table 1. Marine organisms collected and analyzed during rainy and autumn seasons of 2017 at the Bay of Bengal (Bangladesh).

\begin{tabular}{|c|c|c|c|c|c|c|c|}
\hline 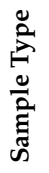 & $\begin{array}{c}\text { Name of the } \\
\text { Organism/Local } \\
\text { Name }\end{array}$ & $\begin{array}{l}\text { Scientific } \\
\text { Name }\end{array}$ & $\begin{array}{l}\text { Range of the } \\
\text { Weight in gm }\end{array}$ & $\begin{array}{l}\text { Range of the } \\
\text { Length in cm }\end{array}$ & $\begin{array}{l}\text { Average } \\
\text { Moisture }\end{array}$ & $\begin{array}{l}\text { Total } \\
\text { Sample Weight } \\
\text { in Kg }\end{array}$ & $\begin{array}{l}\text { Sampling } \\
\text { Location and } \\
\text { Season }\end{array}$ \\
\hline \multirow{12}{*}{ 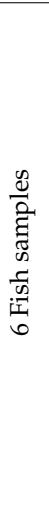 } & \multirow{2}{*}{$\begin{array}{l}\text { Hilsa fish/ } \\
\text { Ilish fish }\end{array}$} & \multirow{2}{*}{$\begin{array}{l}\text { Tenualosa } \\
\text { ilisha }\end{array}$} & $588-626$ & $38.0-38.5$ & \multirow{2}{*}{$86.01 \%$} & 1.214 & (L-1) and R \\
\hline & & & $274-306$ & $29.0-30.0$ & & 1.204 & $(\mathrm{~L}-2)$ and $\mathrm{A}$ \\
\hline & \multirow{2}{*}{$\begin{array}{l}\text { Bombay duck/ } \\
\text { Lotia fish }\end{array}$} & \multirow{2}{*}{$\begin{array}{l}\text { Harpodon } \\
\text { neherues }\end{array}$} & $62-102$ & $22.0-25.5$ & \multirow{2}{*}{$90.22 \%$} & 0.844 & (L-1) and R \\
\hline & & & $22-88$ & $18.0-27.0$ & & 0.890 & (L-2) and A \\
\hline & \multirow{2}{*}{$\begin{array}{l}\text { Flathead sillago/ } \\
\text { Sundara Baila }\end{array}$} & \multirow{2}{*}{$\begin{array}{l}\text { Sillaginopsis } \\
\text { panijus }\end{array}$} & $82-150$ & $25.0-29.0$ & \multirow{2}{*}{$83.01 \%$} & 0.960 & (L-1) and R \\
\hline & & & $168-320$ & $30.0-38.0$ & & 1.152 & (L-1) and A \\
\hline & \multirow{2}{*}{$\begin{array}{l}\text { Indian oil sardine/ } \\
\text { Colombo fish }\end{array}$} & \multirow{2}{*}{$\begin{array}{l}\text { Sardinella } \\
\text { longiceps }\end{array}$} & $50-68$ & $18.5-19.5$ & \multirow{2}{*}{$77.85 \%$} & 1.014 & (L-1) and R \\
\hline & & & $42-62$ & $18.5-20.5$ & & 1.176 & (L-1) and A \\
\hline & \multirow{2}{*}{$\begin{array}{l}\text { Belt fish/ } \\
\text { Churi Fish }\end{array}$} & \multirow{2}{*}{$\begin{array}{l}\text { Trichiurus } \\
\text { lepturus }\end{array}$} & 84-106 & $44.0-51.0$ & \multirow{2}{*}{$80.88 \%$} & 0.964 & (L-1) and R \\
\hline & & & $240-322$ & $62.0-73.0$ & & 1.116 & (L-1) and A \\
\hline & \multirow{2}{*}{$\begin{array}{l}\text { Dotted gizzard } \\
\text { shad/Shard fish }\end{array}$} & \multirow{2}{*}{$\begin{array}{l}\text { Konosirus } \\
\text { punctatus }\end{array}$} & $270-292$ & $22.0-25.0$ & \multirow{2}{*}{$73.41 \%$} & 0.850 & $(\mathrm{~L}-1)$ and $\mathrm{R}$ \\
\hline & & & $255-285$ & $21.0-23.0$ & & 0.820 & $(\mathrm{~L}-1)$ and $\mathrm{A}$ \\
\hline \multirow{8}{*}{ 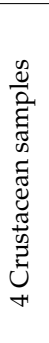 } & \multirow{2}{*}{$\begin{array}{c}\text { Three-spot } \\
\text { swimming crab }\end{array}$} & \multirow{2}{*}{$\begin{array}{l}\text { Portunus san- } \\
\text { guinolentus }\end{array}$} & 90-140 & - & \multirow{2}{*}{$76.44 \%$} & 1.452 & (L-3) and R \\
\hline & & & $93-145$ & - & & 1.485 & (L-3) and A \\
\hline & \multirow{2}{*}{ Mud crab } & \multirow{2}{*}{$\begin{array}{l}\text { Scylla } \\
\text { serrata }\end{array}$} & $60-120$ & - & \multirow{2}{*}{$82.82 \%$} & 1.441 & $(\mathrm{~L}-4)$ and $\mathrm{R}$ \\
\hline & & & 55-120 & - & & 1.411 & (L-4) and A \\
\hline & \multirow{2}{*}{$\begin{array}{l}\text { Asian Shore crab/ } \\
\text { Chati Kakra }\end{array}$} & \multirow{2}{*}{$\begin{array}{l}\text { Hemigrapsus } \\
\text { takanoi }\end{array}$} & $8-18$ & - & \multirow{2}{*}{$78.00 \%$} & 1.438 & (L-3) and R \\
\hline & & & $8-20$ & - & & 1.410 & $(\mathrm{~L}-3)$ and $\mathrm{A}$ \\
\hline & \multirow{2}{*}{$\begin{array}{l}\text { Cat tiger shrimp/ } \\
\text { Harina Chingri }\end{array}$} & \multirow{2}{*}{$\begin{array}{c}\text { Penaeus } \\
\text { semisulcatus }\end{array}$} & $12-24$ & $12.0-14.5$ & \multirow{2}{*}{$76.51 \%$} & 0.880 & (L-1) and R \\
\hline & & & $10-26$ & $12.0-16.0$ & & 0.850 & (L-1) and A \\
\hline
\end{tabular}

Note: (L-1)—Fishery Ghat, Chattogram; (L-2)—Gohira Fishery Ghat, Anwara, Chattogram; (L-3)-Ganga Bari Fish Market, Chattogram; (L-4)-Hazari Goli Seafood Market, Chattogram; R-rainy season and A-autumn season.

Each sample was sun-dried at least one week to remove the extra water and subsequently oven-dried at about $70{ }^{\circ} \mathrm{C}$ to obtain a constant weight. The samples were then re-weighed to determine the dry/wet ratio. Finally, the dried samples were ground, sieved for homogeneity, and stored in clean and dry uncontaminated empty cylindrical plastic containers of uniform size $(2.8 \mathrm{~cm} \times 8.0 \mathrm{~cm})$, sealed with wide vinyl adhesive tapes around their screw necks to air tighten for succeeding uses.

For the trace metal determination, a part of the powdered samples was kept aside in clean and dry sealable plastic bags and kept in an air-tight glass jar to save the samples from any types of chemical reactions. Five grams of the homogenized powder were taken from each specimen and placed in a $250 \mathrm{~mL}$ digestion beaker. A digestion mixture containing $6.0 \mathrm{~mL}$ of high purity nitric acid $(70 \%)$ and $2.0 \mathrm{~mL}$ of hydrochloric acid $(37 \%)$ were added and heated at $60{ }^{\circ} \mathrm{C}$ for half an hour. After cooling down for $15 \mathrm{~min}, 4.0 \mathrm{~mL}$ of hydrogen peroxide $(30 \%)$ was added to each beaker and heated until a clear solution was obtained and the volume decreased into half of its original volume following the standard operating procedure described elsewhere [18]. The digested portions were filtered through Whatman filter paper (No. 42) and diluted to a final volume of $50 \mathrm{~mL}$ using de-ionized water.

\subsection{Methods for Determining Radioactivity and Trace Metals}

\subsubsection{Gamma Spectrometry Analysis}

For the natural and artificial radioactivity measurement of each sample, about $100 \mathrm{~g}$ of dried fish/crustacean samples were weighed and placed in individual plastic containers. The samples were kept 4 weeks before the analysis in airtight conditions to allow secular equilibrium between thorium and radium and their short-lived progenies [14].

The activity concentrations of ${ }^{226} \mathrm{Ra},{ }^{232} \mathrm{Th},{ }^{40} \mathrm{~K}$, and ${ }^{137} \mathrm{Cs}$ in the samples were determined using an NATS GCD-40 190 p-type HPGe (Baltic Scientific Instruments, Riga, Latvia), gamma-ray spectrometer ( $63.3 \mathrm{~mm}$ crystal diameter, $61.3 \mathrm{~mm}$ thickness, $+2200 \mathrm{~V}$ 
operating bias voltage). The low background detector of relative efficiency of $43.1 \%$ and an energy resolution of $1.74 \mathrm{keV}$ full width at half maximum (FWHM) at the $1332 \mathrm{keV}$ peak of ${ }^{60} \mathrm{Co}$ was enclosed in a cylindrical lead shield. The counting system was connected to an $8 \mathrm{k}$ multi-channel analyzer (MCA 527, GBS Elektronik GmbH) with associated electronics for data acquisition of photo-peak areas. A Spectral Line $\mathrm{GP}^{\odot}$ was used to analyze the gammaray counts received from the samples. Energy calibration and the absolute photo-peak efficiency evaluation were performed using standard reference material (Code: 8501-EGSVE, Eckert and Ziegler Analytics), diluted with a multi-nuclide gamma-ray source $\left({ }^{241} \mathrm{Am}\right.$, ${ }^{109} \mathrm{Cd},{ }^{57} \mathrm{Co},{ }^{139} \mathrm{Ce},{ }^{113} \mathrm{Sn},{ }^{85} \mathrm{Sr},{ }^{137} \mathrm{Cs},{ }^{88} \mathrm{Y},{ }^{60} \mathrm{Co}$ ) having homogeneously distributed activity, and maintaining the same geometry and density as the plastic containers containing the samples. To minimize the statistical counting error, the samples were counted for a period of $30,000 \mathrm{~s}$. An empty container was also counted under the same conditions to determine the background counts. To calculate the specific activities, the background counts for the same counting condition were deducted from the counts of each sample to obtain the net counts. For spectrum analyses, the single transition gamma-ray line $1460.822 \mathrm{keV}$ was used to determine the activity concentrations of ${ }^{40} \mathrm{~K}$. The gamma-ray photo-peaks of $295.221 \mathrm{keV}$ and $351.922 \mathrm{keV}$ from ${ }^{214} \mathrm{~Pb}$, and $609.320 \mathrm{keV}, 1120.310 \mathrm{keV}$ and $1764.551 \mathrm{keV}$ from ${ }^{214} \mathrm{Bi}$ were used to determine the activity concentrations of ${ }^{226} \mathrm{Ra}$. The activity concentrations of ${ }^{232} \mathrm{Th}$ were determined using the net counts under the $238.630 \mathrm{keV}$ and $300.087 \mathrm{keV}$ photopeaks from ${ }^{212} \mathrm{~Pb}, 911.205 \mathrm{keV}$ and $968.970 \mathrm{keV}$ photo peaks from ${ }^{228} \mathrm{Ac}$, and $583.190 \mathrm{keV}$ and $2614.533 \mathrm{keV}$ from ${ }^{208} \mathrm{Tl}$. For the evaluation of ${ }^{226} \mathrm{Ra}$ and ${ }^{232} \mathrm{Th}$ activity, a weighted mean approach was applied using the aforementioned gamma lines $[19,20]$. Much care was taken to prevent contamination during the investigation.

\subsubsection{Determination of Trace Metals}

The fish and crustacean samples were analyzed for eight trace elements, $\mathrm{Cd}, \mathrm{Pb}$, $\mathrm{Zn}, \mathrm{Cu}, \mathrm{Ni}, \mathrm{Fe}, \mathrm{Mn}$, and $\mathrm{Cr}$, using an atomic absorption spectrophotometer (HITACHI Z-2000) [21]. Four standard solutions of different known concentrations were prepared, and the elemental concentrations in the unknown samples were determined by extrapolation from the calibration curve. The digested samples were directly aspirated into the flame (air-acetylene fuel mixture). The concentration corresponding to the absorption in the digest was determined by using the absorption mode. The minimum detection limits of the analyzer for the investigated trace metals in ppm are $0.002(\mathrm{Cd}), 0.010(\mathrm{Cu}), 0.005(\mathrm{Zn})$, $0.050(\mathrm{~Pb}), 0.010(\mathrm{Mn}), 0.020(\mathrm{Fe}), 0.020(\mathrm{Ni})$, and $0.020(\mathrm{Cr})$ [22]. The limits of detection (LODs) for all the elements analyzed in the samples were calculated as the blank signal plus three times its standard deviation, whereas the limit of quantification (LOQ) was calculated as ten times the standard deviation of the blank signal, following $[23,24]$. The recovery estimation was performed by the laboratory during method development and validation processes using standard reference materials (SRMs) and certified reference materials (CRMs). However, this time we used secondary reference material made from commercial standard solutions of each element. At each step of the digestion processes, acid blanks (laboratory blank) were prepared to ensure that the samples and chemicals used were not contaminated. Each set of digestion had its acid blank and was corrected by using its blank. The measurement of each sample was taken three times. All the experimental values were reported as mean value \pm standard deviation (SD). Throughout the analysis, all the trace metal standards were prepared and run to check the precision of the instrument. The quality control and quality assurance protocol set by the U.S. Environmental Protection Agency for metal analysis were used. The quality assurance testing relied on the blank controls, and the yield of the chemical procedure was used. 


\subsection{Radiation Dose and Risk Assessment}

\subsubsection{Radiation Dose Assessment}

\section{Activity Concentration}

The activity concentrations $\left(\mathrm{Bq} \mathrm{kg}^{-1}\right)$ of the natural and anthropogenic radionuclides in the measured samples were evaluated by the following equation [25]:

$$
\mathrm{A}\left(\mathrm{Bq} \mathrm{kg}^{-1}\right)=\frac{\mathrm{CPS} \times 1000}{\varepsilon_{\gamma} \mathrm{I}_{\gamma} \mathrm{M}}
$$

where CPS $=$ net count per second (i.e., $\mathrm{CPS}$ for sample $-\mathrm{CPS}$ for background), $\varepsilon_{\gamma}=$ detector efficiency of the specific $\gamma$-ray, $\mathrm{I}_{\gamma}=$ intensity of the gamma-ray, and, $\mathrm{M}=$ mass of the sample in grams.

The errors of the measurements were expressed in terms of the standard deviation of the $\pm 1 \sigma$ level.

\section{Total Effective Dose}

Annual effective dose is a useful concept that enables the radiation doses from different radionuclides and from different types of sources of radioactivity to be added. Estimation of the radiation-induced health effects associated with the intake of radionuclides in the body is proportional to the total dose delivered by the radionuclides while resident in the various organs. Radiation doses ingested are obtained by measuring radionuclide activity in foodstuffs $\left(\mathrm{Bqkg}^{-1}\right)$ and multiplying these by the masses of food consumed over a certain period $\left(\mathrm{kgd}^{-1}\right.$ or kgy $\left.{ }^{-1}\right)$. A dose conversion factor $\left(\mathrm{SvBq}^{-1}\right)$ can then be applied to give an estimate of the ingestion dose. Thus, the ingested dose is given by [26,27]:

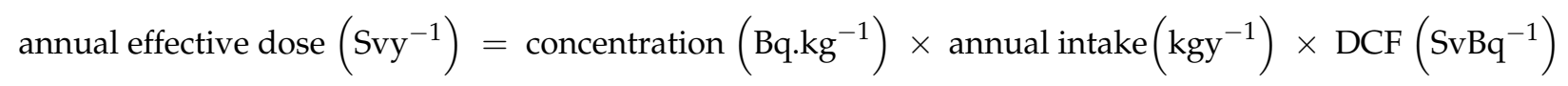

where DCF is the standard dose conversion factor, which is equal to $0.2800 \mu \mathrm{SvBq}^{-1}$ for ${ }^{226} \mathrm{Ra}, 0.2300 \mu \mathrm{SvBq}^{-1}$ for ${ }^{232} \mathrm{Th}$, and $0.0062 \mu \mathrm{SvBq}^{-1}$ for ${ }^{40} \mathrm{~K}$ [25].

Therefore, the total effective dose $\left(\mathrm{Svy}^{-1}\right)$ via ingestion is calculated by the following formula:

total annual effective dose $=\left\{\mathrm{C}_{\mathrm{R}}\left({ }^{226} \mathrm{Ra}\right) \times \mathrm{I}_{\mathrm{F}} \times \mathrm{E}_{\mathrm{D}}\right\}+\left\{\mathrm{C}_{\mathrm{R}}\left({ }^{232} \mathrm{Th}\right) \times \mathrm{I}_{\mathrm{F}} \times \mathrm{E}_{\mathrm{D}}\right\}+\left\{\mathrm{C}_{\mathrm{R}}\left({ }^{40} \mathrm{~K}\right) \times \mathrm{I}_{\mathrm{F}} \times \mathrm{E}_{\mathrm{D}}\right\}$

where $C_{R}$ is the concentration of radionuclides in ingested fish/crustaceans $\left(\mathrm{Bqkg}^{-1}\right)$, $\mathrm{I}_{\mathrm{F}}$ is the annual intake $\left(\mathrm{kgy}^{-1}\right)$ of fish/crustaceans containing radionuclides, and $E_{D}$ is the ingestion dose conversion factor for radionuclides $\left(\mathrm{SvBq}^{-1}\right)$. The intake rates for Bangladeshi consumers were taken from the "Year Book of Fisheries Statistics of Bangladesh 2018" [28].

\subsubsection{Radiation Risk Assessment Internal Hazard Index $\left(\mathrm{H}_{\mathrm{in}}\right)$}

Radon and its short-lived descendants are hazardous to the respiratory organs. The internal hazard index $\left(\mathrm{H}_{\text {in }}\right)$ is used to quantify the internal exposure to radon and its progenies, which is given by the equation:

$$
\mathrm{H}_{\text {in }}=\frac{\mathrm{C}_{\mathrm{Ra}}}{185}+\frac{\mathrm{C}_{\mathrm{Th}}}{259}+\frac{\mathrm{C}_{\mathrm{K}}}{4810}
$$

where $C_{R a}, C_{T h}$, and $C_{K}$ are the concentration $\left(\mathrm{Bqkg}^{-1}\right)$ of $\mathrm{Ra}$, Th, and $\mathrm{K}$, respectively.

The values of the internal hazard index $\left(\mathrm{H}_{\mathrm{in}}\right)$ must be less than unity for the radiation hazard to be negligible $[29,30]$. 


\section{Excess Lifetime Cancer Risk (ELCR)}

Nowadays, cancer is called a life-threatening disease, and the percentage of this disease increases all over the world, including in Bangladesh, due to various reasons. One of the reasons is the effect of radiation on the biological cells, which contributes to a greater extent to increasing cancer incidence. An effort was made to assess the excess lifetime cancer risk due to the ingestion of marine fish and crustaceans by the procedure proposed by the United States Environmental Protection Agency (USEPA) [31]. The following equation was used to calculate the excess lifetime cancer risk [12,32]:

$$
\mathrm{ELCR}=\mathrm{A}_{\mathrm{ir}} \times \mathrm{A}_{\mathrm{ls}} \times \mathrm{R}_{\mathrm{c}}
$$

where ELCR, $A_{i r}, A_{l s}$, and $R_{c}$ are the excess lifetime cancer risk, the annual intake of radionuclide $(\mathrm{Bq})$, the average lifespan $72 \mathrm{yr}$. (life expectancy of a male and a female are 70.6 years and 73.5 years, respectively in Bangladesh [33]), and the mortality cancer risk coefficient $\left(\mathrm{Bq}^{-1}\right)$, respectively. The values of mortality cancer risk coefficients are $9.56 \times 10^{-9} \mathrm{~Bq}^{-1}$ for ${ }^{226} \mathrm{Ra}, 2.45 \times 10^{-9} \mathrm{~Bq}^{-1}$ for ${ }^{232} \mathrm{Th}$, and $5.89 \times 10^{-10} \mathrm{~Bq}^{-1}$ for ${ }^{40} \mathrm{~K}[12,31]$. The acceptable ELCR limit is $10^{-3}$ for radiological risk in general [32,34].

\subsection{Health Risk Assessment of Trace Metals}

2.4.1. Estimated Daily Intake (EDI)

EDI is measured by the following equation in $\left(\mathrm{mgkg}^{-1}\right.$ body weight per day) [35]:

$$
\mathrm{EDI}=\frac{\mathrm{E}_{\mathrm{F}} \times \mathrm{E}_{\mathrm{D}} \times \mathrm{F}_{\mathrm{IR}} \times \mathrm{C}_{\mathrm{f}} \times \mathrm{C}_{\mathrm{M}}}{\mathrm{W}_{\mathrm{AB}} \times \mathrm{AT}_{\mathrm{n}}} \times 10^{-3}
$$

where $E_{F}$ is the exposure frequency ( 365 days per year), $E_{D}=72$ years is the exposure duration, $F_{I R}$ is the ingestion rate, which is taken as $62.58 \mathrm{~g}$ per person per day [28], $C_{f}$ is the conversion factor $\left(C_{f}=0.208\right)$ to convert fresh weight to dry weight considering $79 \%$ of moisture content of the fish fillet $[35,36], \mathrm{C}_{\mathrm{M}}$ is the metal concentration in fish fillet $\left(\mathrm{mgkg}^{-1}\right.$ dry weight basis), $\mathrm{W}_{\mathrm{AB}}$ is the average body weight $(60 \mathrm{~kg})$ of Bangladeshi adult people [37], and $\mathrm{AT}_{\mathrm{n}}$ (equal to $\mathrm{E}_{\mathrm{F}} \times \mathrm{E}_{\mathrm{D}}$ ) is the average exposure time for non-carcinogens [35].

Several organizations such as WHO, FAO, etc., provided guidelines on the intake of metals by a human. The maximum tolerable daily intake (MTDI), provisional tolerable daily intake (PTDI), and the acceptable daily intake (ADI) are used to describe the safe levels of intake for several toxins, including toxic metals. The EDI of trace metals measures the amount of metal intake by an adult $(60 \mathrm{~kg})$ by ingestion of fish or crustaceans per day.

\subsubsection{Target Hazard Quotient (THQ)}

The THQ is non-carcinogenic risk and is dimensionless. In this study, the noncarcinogenic health risks associated with the consumption of fish and crustacean species were assessed based on the target hazard quotients (THQs), and their calculations were done using the standard assumption for an integrated USEPA risk analysis as follows [38]:

$$
\mathrm{THQ}=\frac{\mathrm{E}_{\mathrm{F}} \times \mathrm{E}_{\mathrm{D}} \times \mathrm{F}_{\mathrm{IR}} \times \mathrm{C}_{\mathrm{f}} \times \mathrm{C}_{\mathrm{M}}}{\mathrm{W}_{\mathrm{AB}} \times \mathrm{AT}_{\mathrm{n}} \times \mathrm{RfD}} \times 10^{-3}
$$

$E_{F}, E_{D}, F_{I R}, C_{f}, C_{M}, W_{A B}$, and $A_{n}$ are explained in the earlier section. RfD is the reference dose of individual metal $(\mathrm{mg} / \mathrm{kg} /$ day) (Table 2). The RfD represents an estimate of the daily exposure to which the human population may be continually exposed over a lifetime without a significant risk of deleterious effects. If the THQ is less than 1, the exposed population is unlikely to experience obvious adverse effects. If the THQ is equal to or higher than 1, then there is a potential health risk [39], and related interventions and protective measurements should be taken. 
Table 2. Reference dose (RfD) and carcinogenic slope factor (CSFo), oral.

\begin{tabular}{cccc}
\hline Trace Elements & RfD(Mg/Kg/Day) & $\begin{array}{c}\text { CSFo(Mg/Kg } \\
\text { bw/Day) }\end{array}$ & Reference of CSFo \\
\hline $\mathrm{Pb}$ & $4 \times 10^{-3}$ & $8.5 \times 10^{-3}$ & {$[37]$} \\
\hline $\mathrm{Cu}$ & $4 \times 10^{-2}$ & - & {$[37]$} \\
\hline $\mathrm{Zn}$ & $3 \times 10^{-1}$ & - & {$[40]$} \\
\hline $\mathrm{Mn}$ & $1.4 \times 10^{-1}$ & - & {$[40]$} \\
\hline $\mathrm{Cd}$ & $1 \times 10^{-3}$ & $1.5 \times 10^{1}$ & {$[41]$} \\
\hline $\mathrm{Ni}$ & $2 \times 10^{-2}$ & $1.7 \times 10^{0}$ & {$[40]$} \\
\hline $\mathrm{Cr}$ & $3 \times 10^{-3}$ & $5 \times 10^{-1}$ & {$[41]$} \\
\hline $\mathrm{Fe}$ & $7 \times 10^{-1}$ & - & {$[40]$} \\
\hline
\end{tabular}

\subsubsection{Hazard Index (HI)}

To estimate the overall potential health risk related with more than one metal, THQ of every metal is summed up and referred to as hazard index (HI). The HI can be calculated by the sum of the target hazard quotients (THQs) of each metal:

$\mathrm{HI}=\mathrm{THQMn}+\mathrm{THQFe}+\mathrm{THQCu}+\mathrm{THQZn}+\mathrm{THQPb}+\mathrm{THQCd}+\mathrm{THQCr}+\mathrm{THQNi}$

\subsubsection{Target Cancer Risk}

For carcinogens, the target cancer risk (lifetime cancer risk) is estimated as the incremental probability of an individual to develop cancer over a lifetime exposure to that potential carcinogen (i.e., incremental or excess individual lifetime cancer risk) [38]. Acceptable risk levels for carcinogens range from $10^{-4}$ (risk of developing cancer over a human lifetime is 1 in 10,000 ) to $10^{-6}$ (risk of developing cancer over a human lifetime is 1 in $1,000,000)$. The equation used for estimating the target cancer risk, which is dimensionless, is as follows [38]:

$$
\mathrm{TR}=\frac{\mathrm{E}_{\mathrm{F}} \times \mathrm{E}_{\mathrm{D}} \times \mathrm{F}_{\mathrm{IR}} \times \mathrm{C}_{\mathrm{f}} \times \mathrm{C}_{\mathrm{M}} \times \mathrm{CSF}_{\mathrm{o}}}{\mathrm{W}_{\mathrm{AB}} \times \mathrm{AT}_{\mathrm{C}}} \times 10^{-3}
$$

Here, CSFo is the oral carcinogenic slope factor $\left(\mathrm{mg} / \mathrm{kg} \mathrm{BW} /\right.$ day) ${ }^{-1}$, and ATc (equal to $\left.E_{F} \times E_{D}\right)$ is the average exposure time for carcinogens. Since $\mathrm{Mn}, \mathrm{Fe}, \mathrm{Cu}$, and $\mathrm{Zn}$ do not cause any carcinogenic effects, their CSFo have yet not been established in USEPA 2012. Thus, TR values for the intake of $\mathrm{Pb}, \mathrm{Cd}, \mathrm{Cr}$, and $\mathrm{Ni}$ were calculated to show the carcinogenic risk using oral carcinogenic slope factors (CSFo) of these toxic elements given in Table 2.

\section{Results and Discussion}

Chattogram is the second largest city in Bangladesh, where the main seaport of Bangladesh is located on the bank of the Karnaphuli river. The Chattogram seaport handles ninety per cent of Bangladesh's export-import trade and has been used by India, Nepal, and Bhutan to join for transshipment. There are thousands of industries including a textile mill, cement factory, tannery, oil refinery, dichlorodiphenyltrichloroethane (DDT) plant, chemical factory, fertilizer factory, paper mills, power plant, dry-dock, paint factory, rayon mills, etc., situated near to the bank of the Karnaphuli river, among which about 200 are identified as pollution causing units continuously discharging unlawfully a huge amount of pollutants that finally enter into the Bay of Bengal [42]. The wastes coming from the municipal sewage system through many canals of Chattogram city is another potential factor of the pollution problem of this bay. Moreover, illegal and/or accidental discharges of grease, fish oil, bilge, garbage, etc., from the merchant and fishing vessels are causing pollution to the Bay of Bengal [43]. 


\subsection{Radiation Dose and Risk Assessment by Radioactivity Analysis}

Marine fish and crustaceans are potential bio-indicators when they accumulate the target radionuclides from surrounding waters $[15,44]$. Monitoring radionuclide levels in fish and crustaceans is of great importance due to their significant contribution to the natural radiation dose received by human beings consuming them [45].

Among all the fish and crustacean samples, ${ }^{226} \mathrm{Ra}$ was detected only in Harpodon neherues, and its value was $5 \pm 2 \mathrm{Bqkg}^{-1}$. There was no anthropogenic radionuclide $\left({ }^{137} \mathrm{Cs}\right)$ in any sample. In all the studied fish samples, mean activity concentrations of ${ }^{232} \mathrm{Th}$ and ${ }^{40} \mathrm{~K}$ ranged from $7 \pm 1$ to $190 \pm 10$ and $210 \pm 50$ to $360 \pm 40 \mathrm{Bqkg}^{-1}$, respectively. Similarly, in crustacean samples, the activity concentrations of ${ }^{232} \mathrm{Th}$ and ${ }^{40} \mathrm{~K}$ ranged from $5.0 \pm 2$ to $53 \pm 10$ and $130 \pm 40$ to $240 \pm 70 \mathrm{Bqkg}^{-1}$, respectively. Further, note that the activity concentrations of ${ }^{40} \mathrm{~K}$ were greater than those of the other radionuclides for all samples (Table 3). Mean values of the activity concentrations of ${ }^{226} \mathrm{Ra},{ }^{232} \mathrm{Th}$, and ${ }^{40} \mathrm{~K}$ in all the fish and crustacean samples were $5 \pm 2,67 \pm 9$, and $250 \pm 50 \mathrm{Bqkg}^{-1}$, respectively.

Table 3. Mean activity concentration $\left(\mathrm{Bqkg}^{-1}\right)$ and excess lifetime cancer risk (ELCR) due to the consumption of natural radionuclide from marine fish and crustacean samples collected at the Bay of Bengal.

\begin{tabular}{|c|c|c|c|c|c|c|c|c|c|c|}
\hline S1. No. & 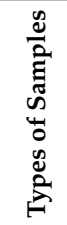 & $\begin{array}{c}\text { Name of } \\
\text { Organism/Local } \\
\text { Name }\end{array}$ & $\begin{array}{l}\text { Scientific } \\
\text { Name }\end{array}$ & 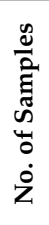 & $\begin{array}{c}\text { Mean } \\
\text { Activity } \\
\text { for }{ }^{226} \mathrm{Ra} \\
\left(\mathrm{Bqkg}^{-1}\right)\end{array}$ & $\begin{array}{c}\text { Mean } \\
\text { Activity } \\
\text { for }{ }^{232} \mathrm{Th} \\
\left(\text { Bqkg }^{-1}\right)\end{array}$ & $\begin{array}{c}\text { Mean } \\
\text { Activity } \\
\text { for }^{40} \mathrm{~K} \\
\left(\mathrm{Bqkg}^{-1}\right)\end{array}$ & $\begin{array}{l}\text { ELCR } \\
\text { for } \\
{ }^{226} \mathrm{Ra}\end{array}$ & $\begin{array}{l}\text { ELCR } \\
\text { for } \\
{ }^{232} \mathrm{Th}\end{array}$ & $\begin{array}{l}\text { ELCR } \\
\text { for } \\
{ }^{40} \mathrm{~K}\end{array}$ \\
\hline 1 & \multirow{6}{*}{$\frac{\frac{5}{9}}{\text { 诖 }}$} & $\begin{array}{l}\text { Hilsa fish/ } \\
\text { Ilish fish }\end{array}$ & $\begin{array}{l}\text { Tenualosa } \\
\text { ilisha }\end{array}$ & 2 & BDL & $7 \pm 1$ & $310 \pm 30$ & BDL & $2.60 \times 10^{-5}$ & $2.96 \times 10^{-4}$ \\
\hline 2 & & $\begin{array}{l}\text { Bombay duck/ } \\
\text { Lotia fish }\end{array}$ & $\begin{array}{l}\text { Harpodon } \\
\text { neherues }\end{array}$ & 2 & $5 \pm 2$ & $170 \pm 30$ & $270 \pm 60$ & $7.07 \times 10^{-5}$ & $6.87 \times 10^{-4}$ & $2.62 \times 10^{-4}$ \\
\hline 3 & & $\begin{array}{l}\text { Flathead sillago/ } \\
\text { Sundara Baila }\end{array}$ & $\begin{array}{l}\text { Sillaginopsis } \\
\text { panijus }\end{array}$ & 2 & BDL & $190 \pm 10$ & $300 \pm 60$ & BDL & $7.60 \times 10^{-4}$ & $2.86 \times 10^{-4}$ \\
\hline 4 & & $\begin{array}{c}\text { Indian oil } \\
\text { sardine/ } \\
\text { Colombo fish }\end{array}$ & $\begin{array}{l}\text { Sardinella } \\
\text { longiceps }\end{array}$ & 2 & BDL & BDL & $210 \pm 50$ & BDL & BDL & $2.03 \times 10^{-4}$ \\
\hline 5 & & $\begin{array}{l}\text { Belt fish/ } \\
\text { Churi fish }\end{array}$ & $\begin{array}{l}\text { Trichiurus } \\
\text { lepturus }\end{array}$ & 2 & BDL & $11 \pm 2$ & $360 \pm 40$ & BDL & $4.23 \times 10^{-5}$ & $3.44 \times 10^{-4}$ \\
\hline 6 & & $\begin{array}{c}\text { Dotted gizzard } \\
\text { shad/ } \\
\text { Shard fish }\end{array}$ & $\begin{array}{l}\text { Konosirus } \\
\text { punctatus }\end{array}$ & 2 & BDL & BDL & $250 \pm 70$ & BDL & BDL & $2.37 \times 10^{-4}$ \\
\hline 7 & \multirow{4}{*}{ 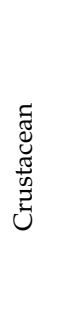 } & $\begin{array}{c}\text { Three-spot } \\
\text { swimming crab }\end{array}$ & $\begin{array}{l}\text { Portunus } \\
\text { sanguino- } \\
\text { lentus }\end{array}$ & 2 & BDL & BDL & $190 \pm 30$ & BDL & BDL & $1.79 \times 10^{-6}$ \\
\hline 8 & & Mud crab & $\begin{array}{l}\text { Scylla } \\
\text { serrata }\end{array}$ & 2 & BDL & $53 \pm 10$ & $240 \pm 70$ & BDL & $2.12 \times 10^{-4}$ & $2.32 \times 10^{-4}$ \\
\hline 9 & & $\begin{array}{c}\text { Asian shore } \\
\text { crab/ } \\
\text { Chati Kakra }\end{array}$ & $\begin{array}{l}\text { Hemigrapsus } \\
\text { takanoi }\end{array}$ & 2 & BDL & $37 \pm 6$ & $220 \pm 50$ & BDL & $1.47 \times 10^{-4}$ & $2.08 \times 10^{-4}$ \\
\hline 10 & & $\begin{array}{c}\text { Cat tiger shrimp/ } \\
\text { Harina Chingri }\end{array}$ & $\begin{array}{l}\text { Penaeus } \\
\text { semisulcatus }\end{array}$ & 2 & BDL & $5 \pm 2$ & $130 \pm 40$ & BDL & $2.01 \times 10^{-5}$ & $1.30 \times 10^{-4}$ \\
\hline
\end{tabular}

Note: BDL-below detection limit.

The comparative data of the present study with the previously reported studies of different radioactive elements in fish and crustacean samples of the Bay of Bengal region are reported in Table 4. It was reported in 2012 that the activity concentrations of ${ }^{226} \mathrm{Ra},{ }^{232} \mathrm{Th}$, and ${ }^{40} \mathrm{~K}$ in sea-fish samples of the Black Sea region of Turkey were $0.06 \pm 0.01$ to $0.96 \pm 0.36$, $0.12 \pm 0.04$ to $1.03 \pm 0.15$, and $35.04 \pm 0.24$ to $127.4 \pm 2.3 \mathrm{Bqkg}^{-1}$, respectively [14].

In all these cases, the results were very much lower than those of the present observations. Conversely, the mean activity concentration of ${ }^{226} \mathrm{Ra},{ }^{232} \mathrm{Th}$, and ${ }^{40} \mathrm{~K}$ in marine fish of the Straits of Malacca was reported as $4.05 \pm 0.48$ to $7.83 \pm 0.78,1.93 \pm 0.24$ to $6.21 \pm 0.53$, and $288 \pm 15$ to $399 \pm 20 \mathrm{Bqkg}^{-1}$, respectively, in 2015 [12], being considerably comparable to the present study except the concentration of ${ }^{232} \mathrm{Th}$. The obtained activity concentration of ${ }^{232} \mathrm{Th}$ and ${ }^{40} \mathrm{~K}$ in all the fish and crustacean samples were $67 \pm 9$ and $250 \pm 50 \mathrm{Bqkg}^{-1}$, respectively, 
which are almost similar to the activity concentration obtained in crab samples from river Odeomi, Ogun State, at the Southwest of Nigeria [46]. It should be noted that if we liken the present study to previous studies for fish $[47,48]$ at the same region, there is a noticeable increment in the levels of different radioactive elements in those marine organisms of the Bay of Bengal region (shown in Table 4). This increment might be due to the wide variety of activities (e.g., housing, tourism, power generation plants, petroleum, steel, shipbuilding, chemical, pharmaceutical, textile, vegetable oil refineries, glass manufacturing industries, etc.) around the Bay of Bengal region, which have been diversified over the years. Multifunctionality and diversification of industries, fisheries, and agriculture are probably linked with these changes in the marine environment. The absence of the anthropogenic radionuclide $\left({ }^{137} \mathrm{Cs}\right)$ indicates that there was not any effect on the marine organisms analyzed due to the post-nuclear disposal of industrial and radioactive waste, underwater nuclear device tests, accidents including leaks from nuclear power plants and from recycling of spent nuclear fuel, etc. As Bangladesh is establishing its first nuclear power plant (NPP) at Rooppur, Pabna, this baseline data can help to further monitor these activities.

Table 4. Comparative data of the radioactivity $\left(\mathrm{Bqkg}^{-1}\right)$ in marine fish and crustacean samples of the Bay of Bengal, Bangladesh.

\begin{tabular}{|c|c|c|c|c|c|c|c|c|c|}
\hline $\begin{array}{l}\text { Sl. } \\
\text { No. }\end{array}$ & $\begin{array}{l}\text { Study } \\
\text { Year }\end{array}$ & $\begin{array}{c}\text { Number } \\
\text { of } \\
\text { Species }\end{array}$ & ${ }^{226} \mathrm{Ra}$ & ${ }^{232} \mathrm{Th}$ & ${ }^{40} \mathrm{~K}$ & ${ }^{137} \mathrm{Cs}$ & ${ }^{238} \mathrm{U}$ & ${ }^{228} \mathrm{Ra}$ & Reference \\
\hline \multicolumn{10}{|c|}{ Fish } \\
\hline 1 & 1995 & 15 & - & $\begin{array}{c}0.31 \pm 0.05 \\
\text { to } \\
1.67 \pm 0.48\end{array}$ & $\begin{array}{c}8.5 \pm 1.2 \\
\text { to } \\
57.1 \pm 5.3\end{array}$ & $\begin{array}{c}\text { BDL } \\
\text { to } \\
1.98 \pm 0.33\end{array}$ & $\begin{array}{c}0.31 \pm 0.05 \\
\text { to } \\
1.19 \pm 0.17\end{array}$ & - & $\begin{array}{c}\text { M. N. } \\
\text { Alam [47] }\end{array}$ \\
\hline 2 & 2000 & 15 & $\begin{array}{c}0.10 \pm 0.03 \\
\text { to } \\
1.66 \pm 0.24\end{array}$ & - & $\begin{array}{c}18.1 \pm 3.4 \\
\text { to } \\
86.4 \pm 6.7\end{array}$ & $\begin{array}{c}0.19 \pm 0.04 \\
\text { to } \\
1.47 \pm 0.28\end{array}$ & - & $\begin{array}{c}0.39 \pm 0.07 \\
\text { to } \\
1.35 \pm 0.19\end{array}$ & $\begin{array}{c}\text { S. Ghose } \\
{[48]}\end{array}$ \\
\hline 3 & 2017 & 2 & - & $\begin{array}{c}8.5 \pm 9.6 \\
\text { to } \\
13 \pm 17\end{array}$ & $\begin{array}{c}265 \pm 417 \\
\text { to } \\
460 \pm 310\end{array}$ & - & $\begin{array}{c}9 \pm 19 \\
\text { to } \\
13 \pm 14\end{array}$ & - & $\begin{array}{c}\text { M. H. } \\
\text { Kabir [49] }\end{array}$ \\
\hline 4 & 2020 & 6 & $\begin{array}{l}\text { BDL } \\
\text { to } \\
5 \pm 2\end{array}$ & $\begin{array}{c}\text { BDL } \\
\text { to } \\
190 \pm 10\end{array}$ & $\begin{array}{c}210 \pm 50 \\
\text { to } \\
360 \pm 40\end{array}$ & BDL & - & - & $\begin{array}{l}\text { Present } \\
\text { Study }\end{array}$ \\
\hline \multicolumn{10}{|c|}{ Crustacean } \\
\hline 1 & 1995 & 5 & - & $\begin{array}{c}0.36 \pm 0.10 \\
\text { to } \\
0.78 \pm 0.23\end{array}$ & $\begin{array}{c}7.32 \pm 0.88 \\
\text { to } \\
16.7 \pm 1.8\end{array}$ & $\begin{array}{c}\text { BDL } \\
\text { to } \\
0.47 \pm 0.07\end{array}$ & $\begin{array}{c}0.11 \pm 0.01 \\
\text { to } \\
0.49 \pm 0.18\end{array}$ & - & $\begin{array}{c}\text { M. N. } \\
\text { Alam [47] }\end{array}$ \\
\hline 2 & 2020 & 4 & BDL & $\begin{array}{c}\text { BDL } \\
\text { to } \\
53 \pm 10\end{array}$ & $\begin{array}{c}130 \pm 40 \\
\text { to } \\
240 \pm 70\end{array}$ & BDL & BDL & - & $\begin{array}{l}\text { Present } \\
\text { Study }\end{array}$ \\
\hline
\end{tabular}

Note: BDL-below detection limit.

The ELCR values of ${ }^{226} \mathrm{Ra},{ }^{232} \mathrm{Th}$, and ${ }^{40} \mathrm{~K}$ in all the fish and crustaceans are shown in Table 3. It is to be mentioned here that ELCR for ${ }^{226} \mathrm{R}$ was below detection level (BDL), except for in Harpodon neherues. However, all of the obtained values (shown in Table 3) were lower than the acceptable ELCR limit of $10^{-3}$ for radiological risk in general, indicating no health hazard to the consumers [32,34].

The estimated annual effective doses due to intake of ${ }^{226} \mathrm{Ra},{ }^{232} \mathrm{Th}$, and ${ }^{40} \mathrm{~K}$ from the consumption of seafood (fish and crabs) from the Bay of Bengal are presented in Table 5, and the comparison between the mean annual effective dose and its world average values are shown in Figure 2. The average annual effective dose for ${ }^{226} \mathrm{Ra}$ and ${ }^{40} \mathrm{~K}$ were found to be within UNSCEAR acceptable limits. Though the average annual effective dose for ${ }^{232} \mathrm{Th}$ was found to be three times greater than the UNSCEAR acceptable limits, the total values of annual effective dose were within the acceptable limits, indicating no threat to the consumers. Maximum and minimum values of the total internal hazard index were $0.79 \pm 0.06$ and $0.04 \pm 0.01$, respectively, and all the values were less than 1 , showing that there is no health hazard to the consumers. 
Table 5. Annual effective dose, total effective dose and total internal hazard index for different radionuclides in marine fish and crustacean samples collected at the Bay of Bengal (Bangladesh) during rainy and autumn seasons of 2017.

\begin{tabular}{|c|c|c|c|c|c|c|c|c|c|}
\hline $\begin{array}{l}\text { Sl. } \\
\text { No. }\end{array}$ & 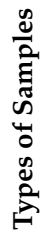 & $\begin{array}{c}\text { Name of the } \\
\text { Organism/Local } \\
\text { Name }\end{array}$ & $\begin{array}{l}\text { Scientific } \\
\text { Name }\end{array}$ & 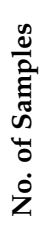 & $\begin{array}{c}\text { Annual } \\
\text { Effective } \\
\text { Dose } \\
\text { for } \\
{ }^{226} \text { Ra } \\
\left(\mathrm{Svy}^{-1}\right)\end{array}$ & $\begin{array}{c}\text { Annual } \\
\text { Effective } \\
\text { Dose } \\
\text { for } \\
{ }^{232} \mathrm{Th} \\
\left(\mathrm{Svy}^{-1}\right)\end{array}$ & $\begin{array}{c}\text { Annual } \\
\text { Effective } \\
\text { Dose } \\
\text { for } \\
{ }^{40} \mathrm{~K} \\
\left(\mathrm{Svy}^{-1}\right)\end{array}$ & $\begin{array}{c}\text { Total } \\
\text { Annual } \\
\text { Effective } \\
\text { Dose } \\
\left(\mathrm{Svy}^{-1}\right)\end{array}$ & $\begin{array}{c}\text { Total } \\
\text { Internal } \\
\text { Hazard } \\
\text { Index } \\
\left(\mathbf{H}_{\mathrm{in}}\right)\end{array}$ \\
\hline 1 & \multirow{6}{*}{$\frac{5}{9}$} & $\begin{array}{l}\text { Hilsa fish/ } \\
\text { Ilish fish }\end{array}$ & $\begin{array}{l}\text { Tenualosa } \\
\text { ilisha }\end{array}$ & 2 & BDL & $3.39 \times 10^{-5}$ & $4.33 \times 10^{-5}$ & $7.72 \times 10^{-5}$ & $0.09 \pm 0.01$ \\
\hline 2 & & $\begin{array}{l}\text { Bombay duck/ } \\
\text { Lotia fish }\end{array}$ & $\begin{array}{l}\text { Harpodon } \\
\text { neherues }\end{array}$ & 2 & $2.88 \times 10^{-5}$ & $8.96 \times 10^{-4}$ & $3.82 \times 10^{-5}$ & $9.63 \times 10^{-4}$ & $0.74 \pm 0.13$ \\
\hline 3 & & $\begin{array}{l}\text { Flathead sillago/ } \\
\text { Sundara Baila }\end{array}$ & $\begin{array}{l}\text { Sillaginopsis } \\
\text { panijus }\end{array}$ & 2 & BDL & $9.90 \times 10^{-4}$ & $4.18 \times 10^{-5}$ & $1.03 \times 10^{-3}$ & $0.79 \pm 0.06$ \\
\hline 4 & & $\begin{array}{c}\text { Indian oil } \\
\text { sardine/ } \\
\text { Colombo fish }\end{array}$ & $\begin{array}{l}\text { Sardinella } \\
\text { longiceps }\end{array}$ & 2 & BDL & BDL & $2.97 \times 10^{-5}$ & $2.97 \times 10^{-5}$ & $0.04 \pm 0.01$ \\
\hline 5 & & $\begin{array}{l}\text { Belt fish/ } \\
\text { Churi Fish }\end{array}$ & $\begin{array}{c}\text { Trichiurus } \\
\text { lepturus }\end{array}$ & 2 & BDL & $5.52 \times 10^{-5}$ & $5.03 \times 10^{-5}$ & $1.05 \times 10^{-4}$ & $0.11 \pm 0.02$ \\
\hline 6 & & $\begin{array}{c}\text { Dotted gizzard } \\
\text { shad/ } \\
\text { Shard fish }\end{array}$ & $\begin{array}{l}\text { Konosirus } \\
\text { punctatus }\end{array}$ & 2 & BDL & BDL & $3.47 \times 10^{-5}$ & $3.47 \times 10^{-5}$ & $0.05 \pm 0.02$ \\
\hline 7 & \multirow{4}{*}{ 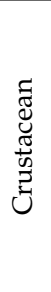 } & $\begin{array}{c}\text { Three-spot } \\
\text { swimming crab }\end{array}$ & $\begin{array}{l}\text { Portunus san- } \\
\text { guinolentus }\end{array}$ & 2 & BDL & BDL & $2.62 \times 10^{-5}$ & $2.62 \times 10^{-5}$ & $0.04 \pm 0.01$ \\
\hline 8 & & Mud crab & $\begin{array}{l}\text { Scylla } \\
\text { serrata }\end{array}$ & 2 & BDL & $2.76 \times 10^{-4}$ & $3.40 \times 10^{-5}$ & $3.10 \times 10^{-4}$ & $0.25 \pm 0.05$ \\
\hline 9 & & $\begin{array}{c}\text { Asian shore crab / } \\
\text { Chati Kakra }\end{array}$ & $\begin{array}{l}\text { Hemigrapsus } \\
\text { takanoi }\end{array}$ & 2 & BDL & $1.92 \times 10^{-4}$ & $3.04 \times 10^{-5}$ & $2.22 \times 10^{-4}$ & $0.19 \pm 0.03$ \\
\hline 10 & & $\begin{array}{l}\text { Cat tiger shrimp/ } \\
\text { Harina Chingri }\end{array}$ & $\begin{array}{c}\text { Penaeus } \\
\text { semisulcatus }\end{array}$ & 2 & BDL & $2.63 \times 10^{-5}$ & $1.90 \times 10^{-5}$ & $4.52 \times 10^{-5}$ & $0.05 \pm 0.02$ \\
\hline
\end{tabular}

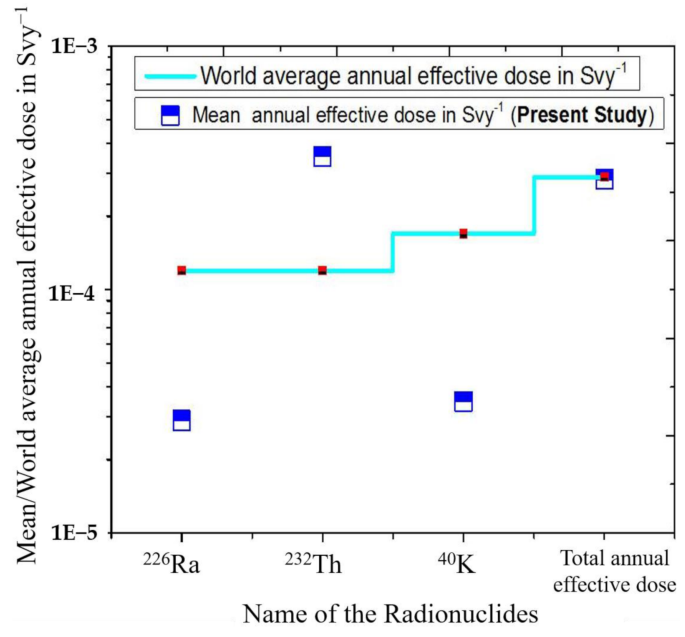

Figure 2. Comparison between the estimated annual effective doses obtained in the present study with the world average values [32].

\subsection{Pollution Level and Health Risk Assessment of Trace Metal Analysis}

\subsubsection{Trace Metal Concentration}

The intake, bioassimilation, and subsequent bioaccumulation of trace metals in marine organisms are significantly affected by the dissimilar aquatic geochemistry of the trace metals as well as the diverse feeding habits and living methods of fish and crustaceans. Among marine animals, fish are possibly one of the most mobile and capable of travelling long distances. Compared to other types of organisms, fish are also on a high trophic level in the food chain; hence, their diet is probably the most diverse of the species studied here. Crustaceans are benthic organisms that usually live on or near the sea floor and are capable 
of travelling some distance. They often feed on organic debris but also on small crustaceans and fish on or near the sea floor. Although the trace metal concentrations in the various species of marine fish and crustaceans analyzed in the present study were in a wide range of variations, these aquatic organisms also showed metal accumulation patterns that were noteworthy (see Table 6).

Table 6. Mean metal concentration $\left(\mathrm{mgkg}^{-1} \mathrm{DW}\right)$ in different marine fish and crustacean samples collected at the Bay of Bengal (Bangladesh) during rainy and autumn seasons of 2017.

\begin{tabular}{|c|c|c|c|c|c|c|c|c|c|c|}
\hline $\begin{array}{l}\text { Name of } \\
\text { the Organ- } \\
\text { ism/Local } \\
\text { Name }\end{array}$ & $\begin{array}{l}\text { Hilsa Fish/ } \\
\text { Ilish Fish }\end{array}$ & $\begin{array}{l}\text { Bombay } \\
\text { Duck } / \\
\text { Lotia Fish }\end{array}$ & $\begin{array}{c}\text { Flathead } \\
\text { Sillago/ } \\
\text { Sundara } \\
\text { Baila }\end{array}$ & $\begin{array}{c}\text { Indian Oil } \\
\text { Sardine/ } \\
\text { Colombo } \\
\text { Fish }\end{array}$ & $\begin{array}{l}\text { Belt Fish/ } \\
\text { Churi Fish }\end{array}$ & $\begin{array}{c}\text { Dotted } \\
\text { Gizzard } \\
\text { Shad/ } \\
\text { Shard Fish }\end{array}$ & $\begin{array}{c}\text { Three- } \\
\text { Spot } \\
\text { Swimming } \\
\text { Crab }\end{array}$ & $\begin{array}{l}\text { Mud } \\
\text { Crab }\end{array}$ & $\begin{array}{l}\text { Asian } \\
\text { Shore } \\
\text { Crab/ } \\
\text { Chati } \\
\text { Kakra }\end{array}$ & $\begin{array}{l}\text { Cat Tiger } \\
\text { Shrimp/ } \\
\text { Harina } \\
\text { Chingri }\end{array}$ \\
\hline $\begin{array}{l}\text { Scientific } \\
\text { name }\end{array}$ & $\begin{array}{l}\text { Tenualosa } \\
\text { ilisha }\end{array}$ & $\begin{array}{l}\text { Harpodon } \\
\text { neherues }\end{array}$ & $\begin{array}{l}\text { Sillaginopsis } \\
\text { panijus }\end{array}$ & $\begin{array}{l}\text { Sardinella } \\
\text { longiceps }\end{array}$ & $\begin{array}{l}\text { Trichiurus } \\
\text { lepturus }\end{array}$ & $\begin{array}{l}\text { Konosirus } \\
\text { punctatus }\end{array}$ & $\begin{array}{l}\text { Portunus } \\
\text { sanguino- } \\
\text { lentus }\end{array}$ & $\begin{array}{l}\text { Scylla } \\
\text { serrata }\end{array}$ & $\begin{array}{l}\text { Hemigrapsus } \\
\text { takanoi }\end{array}$ & $\begin{array}{l}\text { Penaeus } \\
\text { semisulca- } \\
\text { tus }\end{array}$ \\
\hline $\begin{array}{l}\text { Sample } \\
\text { Type }\end{array}$ & \multicolumn{7}{|c|}{ Fish } & \multicolumn{2}{|c|}{ Crustacean } & \\
\hline $\begin{array}{l}\text { No. of } \\
\text { samples } \\
\text { from } \\
\text { two } \\
\text { seasons }\end{array}$ & 2 & 2 & 2 & 2 & 2 & 2 & 2 & 2 & 2 & 2 \\
\hline $\begin{array}{l}\text { Mean Pb } \\
\text { conc. in } \\
\text { mgkg }^{-1} \\
\text { DW }\end{array}$ & $0.19 \pm 0.04$ & $0.25 \pm 0.03$ & $0.37 \pm 0.03$ & $4.6 \pm 0.1$ & $0.37 \pm 0.00$ & $0.12 \pm 0.03$ & $1.4 \pm 0.0$ & $1.6 \pm 0.0$ & $1.4 \pm 0.0$ & $0.12 \pm 0.02$ \\
\hline $\begin{array}{l}\text { Mean Cu } \\
\text { conc. in } \\
\text { mgkg }^{-1} \\
\text { DW }\end{array}$ & $4.1 \pm 0.1$ & $1.7 \pm 0.1$ & $1.6 \pm 0.0$ & $2.6 \pm 0.0$ & $1.9 \pm 0.0$ & $3.4 \pm 0.1$ & $62 \pm 20$ & $100 \pm 0$ & $75 \pm 6$ & $44 \pm 0$ \\
\hline $\begin{array}{l}\text { Mean } \mathrm{Zn} \\
\text { conc. in } \\
\text { mgkg }^{-1} \\
\text { DW }\end{array}$ & $73 \pm 0$ & $58 \pm 0$ & $61 \pm 0$ & $170 \pm 0$ & $63 \pm 0$ & $74 \pm 0$ & $130 \pm 1$ & $140 \pm 1$ & $120 \pm 1$ & $83 \pm 1$ \\
\hline $\begin{array}{l}\text { Mean Mn } \\
\text { conc. in } \\
\text { mgkg }^{-1} \\
\text { DW }\end{array}$ & $16 \pm 0$ & $5.8 \pm 0.0$ & $18 \pm 0$ & $20 \pm 0$ & $11 \pm 0$ & $10 \pm 0$ & $89 \pm 1$ & $610 \pm 1$ & $450 \pm 3$ & $17 \pm 0$ \\
\hline $\begin{array}{l}\text { Mean Cd } \\
\text { conc. in } \\
\text { mgkg }^{-1} \\
\text { DW }\end{array}$ & $0.14 \pm 0.00$ & $0.16 \pm 0.00$ & $0.12 \pm 0.00$ & $0.39 \pm 0.00$ & $0.11 \pm 0.00$ & $2.0 \pm 0.0$ & $3.3 \pm 0.0$ & $0.52 \pm 0.04$ & $0.10 \pm 0.00$ & $1.8 \pm 0.0$ \\
\hline $\begin{array}{l}\text { Mean } \mathrm{Ni} \\
\text { conc. in } \\
\text { mgkg }^{-1} \\
\text { DW }\end{array}$ & $6.9 \pm 0.1$ & BDL & $0.14 \pm 0.07$ & $0.37 \pm 0.04$ & $1.1 \pm 0.1$ & $2.1 \pm 0.0$ & $1.6 \pm 0.0$ & $1.3 \pm 0.1$ & BDL & $0.16 \pm 0.02$ \\
\hline $\begin{array}{l}\text { Mean Cr } \\
\text { conc. in } \\
\text { mgkg }^{-1} \\
\text { DW }\end{array}$ & $0.45 \pm 0.00$ & $1.2 \pm 0.2$ & $1.8 \pm 0.1$ & $0.58 \pm 0.00$ & $0.79 \pm 0.00$ & $0.79 \pm 0.00$ & $2.0 \pm 0.2$ & $2.8 \pm 0.0$ & $1.8 \pm 0.1$ & $0.70 \pm 0.00$ \\
\hline $\begin{array}{l}\text { Mean Fe } \\
\text { conc. in } \\
\text { mgkg }^{-1} \\
\text { DW }\end{array}$ & $790 \pm 10$ & $5.5 \pm 0.1$ & $140 \pm 1$ & $370 \pm 2$ & $120 \pm 1$ & $130 \pm 1$ & $330 \pm 1$ & $400 \pm 2$ & $560 \pm 3$ & $55 \pm 0$ \\
\hline
\end{tabular}

Note: BDL-below detection limit.

The trace metal concentrations found in individual fish muscles for both rainy and autumn seasons varied for $\mathrm{Pb}, 7.5-0.12$, $\mathrm{Cu}$ : 4.3-1.3; $\mathrm{Zn}, 170-45 ; \mathrm{Mn}, 24-5.5 ; \mathrm{Cd}, 2.1-0.10$; $\mathrm{Ni}, 13-0.28$; $\mathrm{Cr}, 2.6-0.16$; and Fe, $1300-11 \mathrm{mgkg}^{-1}$ dry weight. In addition, in individual crustacean samples of both rainy and autumn seasons, these values varied for $\mathrm{Pb}$, 1.9-0.25; Cu, 100-39; Zn, 150-79; Mn, 640-15; Cd, 3.4-0.09; Ni, 2.3-0.31; Cr, 3.3-0.63; and Fe, 600-9.4 $\mathrm{mgkg}^{-1}$ dry weight.

Most of the chemical elements present in fish and crustaceans are essential for biota at low concentrations; however, high concentrations of these elements can become toxic for them. Similarly, some metals (e.g., Fe, Mn, Ni, Cu, and $\mathrm{Zn}$ ) are necessary for proper metabolic reactions in the human body, and other elements (e.g., $\mathrm{Cd}, \mathrm{Cr}$, and $\mathrm{Pb}$ ) are of unknown benefits and may become toxic in the cases of chronic exposure to humans [50]. The obtained trace metal concentrations in the ten marine fish and crustacean samples analyzed in the present study in the rainy season followed the order of Fe $>\mathrm{Mn}>\mathrm{Zn}>$ 
$\mathrm{Cu}>\mathrm{Ni}>\mathrm{Cr}>\mathrm{Cd}>\mathrm{Pb}$ and in the autumn season followed the order of $\mathrm{Fe}>\mathrm{Mn}>\mathrm{Zn}>$ $\mathrm{Cu}>\mathrm{Cr}>\mathrm{Pb}>\mathrm{Cd}>\mathrm{Ni}$. However, in both seasons, the average concentration followed the order of $\mathrm{Fe}>\mathrm{Zn}>\mathrm{Mn}>\mathrm{Cu}>\mathrm{Ni}>\mathrm{Pb}>\mathrm{Cr}>\mathrm{Cd}$ in fish samples and of $\mathrm{Fe}>\mathrm{Mn}>\mathrm{Zn}>\mathrm{Cu}$ $>\mathrm{Cr}>\mathrm{Cd}>\mathrm{Pb}>\mathrm{Ni}$ in crustacean samples. This demonstrated that marine organisms in different groups had different accumulation mechanisms for trace metals. Additionally, the different concentrations of chemical elements in the marine environment and the age of the marine organisms analyzed may also be responsible for these trends.

The maximum allowed concentration of $\mathrm{Pb}$ in fish is $0.21 \mathrm{mgkg}^{-1} \mathrm{DW}$ set by JECFA [51], whereas in our study we found that the fish Sillaginopsis panijus, Sardinella longiceps, Trichiurus lepturus, and all the crustacean species contained $\mathrm{Pb}$ concentrations exceeding the limit. According to $\mathrm{FAO} / \mathrm{WHO}$, the acceptable limit of $\mathrm{Cd}$ for human consumption is $0.20 \mathrm{mgkg}^{-1}$ [52]. Among the fish species, Sardinella longiceps, Konosirus punctatus, and among the crustacean species Portunus sanguinolentus, Scylla serrata, and Penaeus semisulcatus exceeded this limit. In addition, the permissible limit for $\mathrm{Cr}$ is $0.20 \mathrm{mgkg}^{-1} \mathrm{DW}$ set by the National Academic Press, Washington DC, 1989 [51], whereas all the studied samples exceeded this limit. These three trace metals $(\mathrm{Cd}, \mathrm{Cr}$, and $\mathrm{Pb})$ are considered to be toxic and all of them were in an excessive content in some of the studied marine organisms, demonstrating that the aquatic fauna was contaminated by these metals. Other essential trace elements (e.g., $\mathrm{Cu}, \mathrm{Zn}, \mathrm{Mn}, \mathrm{Ni}$, and $\mathrm{Fe}$ ) were also observed in excessive contents in some of the studied samples. This indicates the overall pollution status of the studied area due to industrial activities, fossil fuels, agricultural run-off, ship-breaking activities, and other human activities around the coastline.

A comparison between available fish species metal concentration data and the present study is shown in Table 7. It is evident that the range of concentration of metal elements in other parts of the world are lower than that of the presently studied data [52-56]. On the other hand, the obtained data is comparable to similar studies in the neighboring regions $[57,58]$. If we liken the present study with similar kinds of studies conducted in the Bay of Bengal in the past, the range of metal element concentrations are also comparable [59-61], though it indicates a gradual increment in metal accumulation by the fish of those regions. It seems that day by day, the rate of environmental disturbances and the pollution levels increase due to different reasons, such as the establishment of different industries beside the rivers, which is gradually increasing and also affects the marine environment progressively, contaminating the marine organisms in the long run. Presently, it is an issue of concern for the local populations, but in the near future it might be the threat for the surrounding environment of all organisms, including humans.

Table 7. Trace metal concentrations $\left(\mathrm{mgkg}^{-1} \mathrm{DW}\right)$ in various species of fish from different areas of the world.

\begin{tabular}{|c|c|c|c|c|c|c|c|c|c|c|c|}
\hline $\begin{array}{l}\text { Sl. } \\
\text { No. }\end{array}$ & Area & Species & $\mathrm{Pb}$ & $\mathrm{Cd}$ & $\mathrm{Ni}$ & $\mathrm{Cr}$ & $\mathrm{Cu}$ & $\mathrm{Zn}$ & Mn & $\mathrm{Fe}$ & Ref. \\
\hline 1 & $\begin{array}{c}\text { Bay of } \\
\text { Bengal, } \\
\text { Bangladesh }\end{array}$ & $\begin{array}{l}\text { Five species: } P \text {. } \\
\text { carcinus, W. attu, } \\
\text { S. sinensis, R. rita, } \\
\text { S. sihama, and } B \text {. } \\
\text { strogylurus }\end{array}$ & - & - & $2.70-15.20$ & - & $0.65-66.00$ & $\begin{array}{l}26.00- \\
78.80\end{array}$ & $1.89-7.11$ & $\begin{array}{l}37.90- \\
182.00\end{array}$ & [61] \\
\hline 2 & $\begin{array}{c}\text { Bay of } \\
\text { Bengal, } \\
\text { Bangladesh }\end{array}$ & $\begin{array}{l}\text { Six species: } C \text {. } \\
\text { neglecta, } C \text {. reba, J. } \\
\text { argentus, H. } \\
\text { nehereus, } S . \text { fhasa, } \\
\text { and L. savala }\end{array}$ & $1.67-2.58$ & $0.009-0.17$ & $6.44-7.58$ & - & $3.33-4.69$ & $\begin{array}{l}18.86- \\
33.89\end{array}$ & $5.01-11.14$ & $\begin{array}{l}60.55- \\
451.10\end{array}$ & [59] \\
\hline 3 & $\begin{array}{c}\text { Bay of } \\
\text { Bengal, } \\
\text { Bangladesh }\end{array}$ & $\begin{array}{l}\text { Nine species: } L . \\
\text { calcarifer, } P . \\
\text { pangasius, } P . \\
\text { indicus, } I . \\
\text { megaloptera, } R . \\
\text { russelliana, } L . \\
\text { stylifetus, } R . \\
\text { kanagurta, } S . \\
\text { guttatum, } P \\
\text { paradiseus, and } O . \\
\text { militaris }\end{array}$ & $0.58-4.03$ & $0.04-0.13$ & $0.73-6.11$ & - & $0.46-7.74$ & $\begin{array}{l}25.67- \\
119.36\end{array}$ & $1.46-9.02$ & $\begin{array}{l}37.70- \\
118.91\end{array}$ & [60] \\
\hline
\end{tabular}


Table 7. Cont.

\begin{tabular}{|c|c|c|c|c|c|c|c|c|c|c|c|}
\hline $\begin{array}{l}\text { Sl. } \\
\text { No. }\end{array}$ & Area & Species & $\mathrm{Pb}$ & $\mathrm{Cd}$ & $\mathrm{Ni}$ & $\mathrm{Cr}$ & $\mathrm{Cu}$ & $\mathrm{Zn}$ & Mn & $\mathrm{Fe}$ & Ref. \\
\hline 4 & $\begin{array}{l}\text { Northeast } \\
\text { Coast of the } \\
\text { Bay of } \\
\text { Bengal, } \\
\text { India }\end{array}$ & $\begin{array}{l}\text { Five species: } S \text {. } \\
\text { phasa, P. argentus, } \\
\text { G. sparsipapillus, } \\
\text { L. parsia, and C. } \\
\text { sp. }\end{array}$ & $\begin{array}{l}12.40- \\
19.96\end{array}$ & $0.62-1.20$ & $2.20-3.69$ & ND-3.89 & $\begin{array}{l}16.22- \\
47.97\end{array}$ & $\begin{array}{l}12.13- \\
44.74\end{array}$ & - & - & [57] \\
\hline 5 & $\begin{array}{l}\text { Cuddalore } \\
\text { Coast, Tamil } \\
\text { Nadu, India }\end{array}$ & $\begin{array}{l}\text { Three species: } R \text {. } \\
\text { kanagurta, } K . \\
\text { axillaris, and } S . \\
\text { longiceps }\end{array}$ & - & $0.35-0.43$ & $0.62-0.79$ & $0.66-0.86$ & $0.42-0.61$ & $\begin{array}{l}20.10- \\
26.20\end{array}$ & - & - & [56] \\
\hline 6 & $\begin{array}{l}\text { Rio de } \\
\text { Janeiro, } \\
\text { Brazil }\end{array}$ & $\begin{array}{c}\text { Eleven species: } S \text {. } \\
\text { salar, } S \text {. } \\
\text { brasiliensis, } P \text {. } \\
\text { saltatrix, } M \text {. } \\
\text { furnieri, C. } \\
\text { leiarchus, } C \text {. } \\
\text { crysos, } P \text { arenatus, } \\
\text { M. cephalus, G. } \\
\text { brasiliensis, } L . \\
\text { villarii, and } P \text {. } \\
\text { numida }\end{array}$ & $0.04-0.30$ & $0.001-0.09$ & - & - & $1.20-2.90$ & $2.70-9.30$ & $0.30-1.70$ & $1.60-7.50$ & [55] \\
\hline 7 & $\begin{array}{l}\text { Northeast } \\
\text { Coast of } \\
\text { India }\end{array}$ & $\begin{array}{l}\text { Nine species: } H . \\
\text { nehereus, } T . \\
\text { trichiurus, } S . \\
\text { laticaudus, } D . \\
\text { albida, } P . \\
\text { argentius, A. sp., } \\
\text { F. niger, H. ilisha, } \\
\text { and } R \text {. kanagurta }\end{array}$ & - & $0.01-1.10$ & - & - & $0.50-28.20$ & $3.00-99.10$ & $0.50-12.00$ & $\begin{array}{l}10.40- \\
249.70\end{array}$ & [58] \\
\hline 8 & $\begin{array}{l}\text { Mersing, } \\
\text { Malaysia }\end{array}$ & $\begin{array}{l}\text { Two species: } A \text {. } \\
\text { thalassinus, and } J \text {. } \\
\text { belangeri }\end{array}$ & - & $2.20-2.34$ & - & - & $8.80-12.91$ & $\begin{array}{l}120.91- \\
217.37\end{array}$ & $4.34-9.67$ & - & [52] \\
\hline 9 & $\begin{array}{l}\text { Saudi } \\
\text { Arabia }\end{array}$ & $\begin{array}{l}\text { Three species: } L \text {. } \\
\text { nebulosus, } P . \\
\text { major, and } S \text {. } \\
\text { cantharu }\end{array}$ & $\begin{array}{l}0.002- \\
0.003\end{array}$ & $\begin{array}{l}0.001- \\
0.001\end{array}$ & - & - & $\begin{array}{l}0.026- \\
0.093\end{array}$ & $\begin{array}{l}0.037- \\
0.376\end{array}$ & $\begin{array}{l}0.008- \\
0.036\end{array}$ & $\begin{array}{l}0.222- \\
1.016\end{array}$ & [54] \\
\hline 10 & $\begin{array}{c}\text { Bay of } \\
\text { Bengal, } \\
\text { Bangladesh }\end{array}$ & $\begin{array}{l}\text { Ten species: } L . \\
\text { calcarifer, } P . \\
\text { pangasius, } P . \\
\text { indicus, } I . \\
\text { megaloptera, } A . \\
\text { cruciger, } P . \\
\text { chinensis, } S . \\
\text { phasa, } S . \\
\text { guttatum, C. reba, } \\
\text { and A. arius }\end{array}$ & $0.80-6.26$ & $0.02-0.47$ & $1.88-7.56$ & $1.27-4.66$ & $\leq 8.54$ & $\begin{array}{l}13.22- \\
74.36\end{array}$ & $3.63-17.80$ & - & [35] \\
\hline 11 & $\begin{array}{c}\text { Terengganu } \\
\text { Coastal } \\
\text { Area, } \\
\text { Malaysia }\end{array}$ & $\begin{array}{l}\text { Ten species: } S . \\
\text { leptolepis, } D . \\
\text { maraudsi, } E . \\
\text { lanceolatus, } P . \\
\text { tayenus, } \\
\text { Rastrelliger, } M . \\
\text { cordyla, } N . \\
\text { soldado, } P \\
\text { filamentosus, } \\
\text { Bramidae, and } S . \\
\text { canaliculatus }\end{array}$ & $\begin{array}{c}0.0002- \\
0.007\end{array}$ & $\begin{array}{c}0.0008- \\
0.015\end{array}$ & - & - & $\begin{array}{c}0.0021- \\
0.012\end{array}$ & $\begin{array}{c}0.0488- \\
0.151\end{array}$ & $\begin{array}{c}0.0068- \\
0.041\end{array}$ & $\begin{array}{c}0.3995- \\
0.667\end{array}$ & [53] \\
\hline 12 & $\begin{array}{l}\text { Northwest } \\
\text { Mediter- } \\
\text { ranean } \\
\text { Sea }\end{array}$ & $\begin{array}{l}\text { Six species: } G \text {. } \\
\text { melastomus, } S \text {. } \\
\text { canicula, } H . \\
\text { dactylopterus, } L \text {. } \\
\text { boscii, } M \text {. } \\
\text { poutassou, and } P \text {. } \\
\text { blennoides }\end{array}$ & $0.00-0.90$ & $0.00-0.03$ & $0.02-7.00$ & - & $0.10-10.60$ & $\begin{array}{l}12.10- \\
60.30\end{array}$ & - & - & [7] \\
\hline 13 & $\begin{array}{l}\text { Northeast } \\
\text { Atlantic } \\
\text { Ocean }\end{array}$ & $\begin{array}{l}\text { Six species: } G \text {. } \\
\text { melastomus, } S \text {. } \\
\text { canicula, } H . \\
\text { dactylopterus, } L \text {. } \\
\text { boscii, } M \text {. } \\
\text { poutassou, and } P \text {. } \\
\text { blennoides }\end{array}$ & $0.01-0.26$ & $0.00-0.04$ & $0.00-0.53$ & - & $0.40-5.80$ & $9.90-40.00$ & - & - & [7] \\
\hline 14 & $\begin{array}{c}\text { Bay of } \\
\text { Bengal, } \\
\text { Bangladesh }\end{array}$ & $\begin{array}{c}\text { Six species: T. } \\
\text { ilisha, H. neherues, } \\
\text { S. panijus, } S . \\
\text { longiceps, T. } \\
\text { lepturus, and } K \text {. } \\
\text { punctatus }\end{array}$ & $0.12-4.6$ & $0.11-2$ & BDL-6.9 & $0.45-1.8$ & $1.6-4.1$ & 58-170 & 5.8-20 & $5.5-790$ & PS \\
\hline
\end{tabular}

Note: BDL—below detection limit; ND—not detected; PS—present study. 


\subsubsection{Estimated Daily Intake (EDI)}

EDI and mean EDI values of respective trace elements $(\mathrm{Cd}, \mathrm{Pb}, \mathrm{Zn}, \mathrm{Cu}, \mathrm{Ni}, \mathrm{Fe}, \mathrm{Mn}$, and $\mathrm{Cr}$ ) for the fish and crustacean samples of both seasons are shown in Table 8. The corresponding Figure 3 shows the comparative results of estimated daily intake (EDI) values with the recommended daily intake (RDI) values. As the values of EDI $<$ RDI for both fish and crustaceans, there is no risk from the consumption of the studied seafood.

Table 8. The values of estimated daily intake (EDI), target hazard quotients (THQ), and hazard index (HI) obtained for the marine fish and crustacean samples collected at the Bay of Bengal (Bangladesh) during rainy and autumn seasons of 2017.

\begin{tabular}{|c|c|c|c|c|c|c|c|c|c|}
\hline \multirow{2}{*}{$\begin{array}{c}\begin{array}{c}\text { Sampling } \\
\text { Time }\end{array} \\
\text { Trace Metals }\end{array}$} & \multicolumn{3}{|c|}{ Rainy Season } & \multicolumn{3}{|c|}{ Autumn Season } & \multirow{2}{*}{$\begin{array}{c}\text { Mean } \\
\text { EDI } \\
\text { (mgkg }^{-1} \\
\text { Body } \\
\text { Weight per } \\
\text { Day) }\end{array}$} & \multirow[b]{2}{*}{ Mean THQ } & \multirow[b]{2}{*}{ HI } \\
\hline & $\begin{array}{c}\text { Average } \\
\text { Concentra- } \\
\text { tion } \\
\left(\mathrm{mgkg}^{-1}\right) \\
\text { DW }\end{array}$ & $\begin{array}{c}\text { EDI } \\
\text { (mgkg }^{-1} \\
\text { Body } \\
\text { Weight per } \\
\text { Day) }\end{array}$ & THQ & $\begin{array}{c}\text { Average } \\
\text { Concentra- } \\
\text { tion } \\
\left(\mathrm{mgkg}^{-1}\right) \\
\text { DW }\end{array}$ & $\begin{array}{c}\text { EDI } \\
\text { (mgkg }^{-1} \\
\text { Body } \\
\text { Weight per } \\
\text { Day) }\end{array}$ & THQ & & & \\
\hline $\mathrm{Pb}$ & 0.79 & $8.29 \times 10^{-4}$ & $4.31 \times 10^{-5}$ & 1.26 & $1.31 \times 10^{-3}$ & $8.54 \times 10^{-5}$ & $1.07 \times 10^{-3}$ & $6.43 \times 10^{-5}$ & \multirow{8}{*}{$8.82 \times 10^{-4}$} \\
\hline $\mathrm{Cu}$ & 27.20 & $2.84 \times 10^{-2}$ & $1.48 \times 10^{-4}$ & 33.10 & $3.45 \times 10^{-2}$ & $1.80 \times 10^{-4}$ & $3.15 \times 10^{-2}$ & $1.64 \times 10^{-4}$ & \\
\hline $\mathrm{Zn}$ & 93.92 & $9.80 \times 10^{-2}$ & $6.79 \times 10^{-5}$ & 98.69 & $1.03 \times 10^{-1}$ & $7.14 \times 10^{-5}$ & $1.01 \times 10^{-1}$ & $6.96 \times 10^{-5}$ & \\
\hline $\mathrm{Mn}$ & 122.51 & $1.28 \times 10^{-1}$ & $1.90 \times 10^{-4}$ & 128.20 & $1.34 \times 10^{-1}$ & $1.99 \times 10^{-4}$ & $1.31 \times 10^{-1}$ & $1.94 \times 10^{-4}$ & \\
\hline $\mathrm{Cd}$ & 0.84 & $8.80 \times 10^{-4}$ & $1.83 \times 10^{-4}$ & 0.88 & $9.18 \times 10^{-4}$ & $1.91 \times 10^{-4}$ & $8.99 \times 10^{-4}$ & $1.87 \times 10^{-4}$ & \\
\hline $\mathrm{Ni}$ & 1.93 & $2.01 \times 10^{-3}$ & $2.09 \times 10^{-5}$ & 0.78 & $8.09 \times 10^{-4}$ & $1.20 \times 10^{-5}$ & $1.41 \times 10^{-3}$ & $1.65 \times 10^{-5}$ & \\
\hline $\mathrm{Cr}$ & 1.29 & $1.35 \times 10^{-3}$ & $9.36 \times 10^{-5}$ & 1.26 & $1.32 \times 10^{-3}$ & $9.15 \times 10^{-5}$ & $1.34 \times 10^{-3}$ & $9.26 \times 10^{-5}$ & \\
\hline $\mathrm{Fe}$ & 308.62 & $3.22 \times 10^{-1}$ & $9.56 \times 10^{-5}$ & 272.24 & $2.84 \times 10^{-1}$ & $9.37 \times 10^{-5}$ & $3.03 \times 10^{-1}$ & $9.47 \times 10^{-5}$ & \\
\hline
\end{tabular}

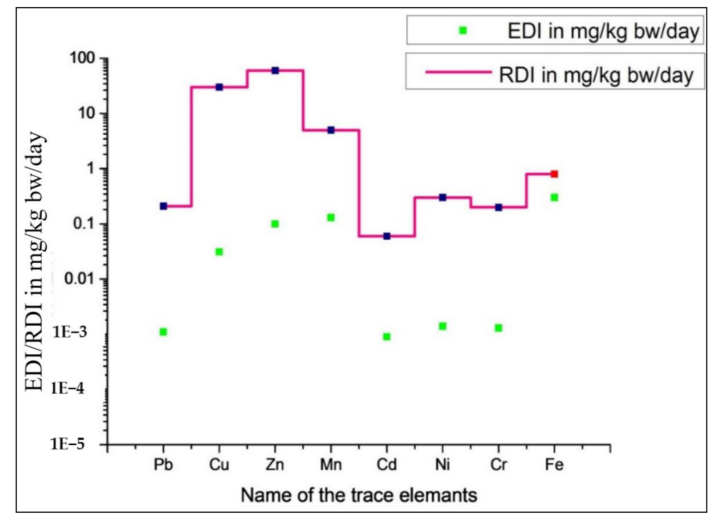

Figure 3. Comparison between estimated daily intake (EDI) values and recommended daily intake (RDI) values obtained in the present study.

\subsubsection{Target Hazard Quotients (THQ)}

The dimensionless target hazard quotient (THQ) is the indicator of non-carcinogenic health risks associated with the consumption of food (fish and crustaceans). The mean THQ values for the trace metals $\mathrm{Pb}, \mathrm{Cu}, \mathrm{Zn}, \mathrm{Mn}, \mathrm{Cd}, \mathrm{Ni}, \mathrm{Cr}$ and $\mathrm{Fe}$ are given in Table 8. After analysis of all the fish and crustacean samples, the obtained THQ values for different metals were less than 1, which indicates that the exposed population is unlikely to experience obvious adverse effects [39].

\subsubsection{Hazard Index (HI)}

The value of the hazard index, which is obtained by the summing of the target hazard quotients of each metal, was used to assess the overall potential health risk posed by more than one metal. The obtained hazard index value was $8.82 \times 10^{-4}$, which is less than 1 , indicating that there are no health hazards to the local consumers (Table 8). 


\subsubsection{Target Cancer Risk (TR)}

The obtained values of target cancer risk for $\mathrm{Pb}, \mathrm{Cd}, \mathrm{Ni}$, and $\mathrm{Cr}$ due to exposure from the consumption of the targeted six fish and four crustacean species analyzed in the present study are shown in Figure 4. Generally, the values of TR lower than $10^{-6}$ are considered as negligible, while those above $10^{-4}$ are considered to be unacceptable, and those in between $10^{-6}$ and $10^{-4}$ are considered as an acceptable range [37]. The present study reveals that only TR for $\mathrm{Pb}$ were below the benchmark and those for $\mathrm{Cd}, \mathrm{Ni}$, and $\mathrm{Cr}$ were above the benchmark, indicating that the fish and the crustaceans were becoming polluted. This also increased the risk of chronic cancer due to exposure of $\mathrm{Cd}, \mathrm{Ni}$, and $\mathrm{Cr}$ through fish and crustacean consumption.

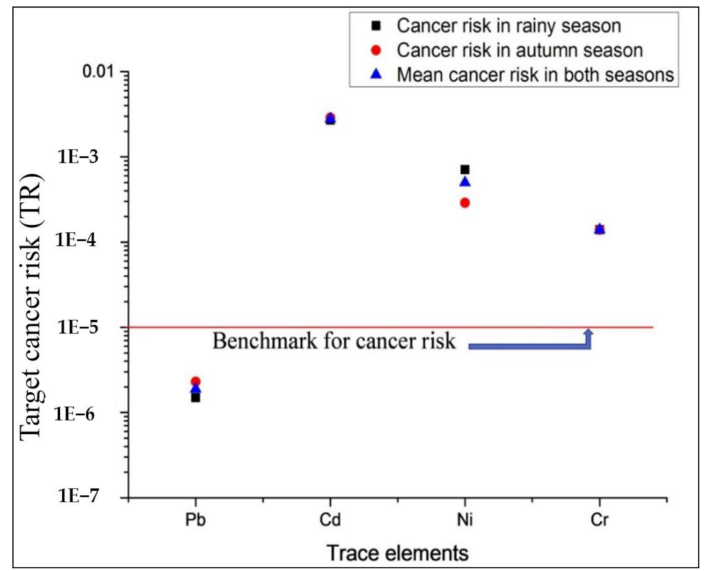

Figure 4. Targeted cancer risk (TR) values for associated toxic element consumption from the studied seafood (fish and crustaceans) at the Bay of Bengal (Bangladesh) during rainy and autumn seasons of 2017.

\section{Conclusions}

The radioactivity and the trace metal concentrations were studied in certain commercially important marine biota (fish and crustaceans) from the Bay of Bengal, Bangladesh, in two different seasons (rainy and autumn). Through the analysis of different radiological parameters, the present study revealed an elevated activity concentration compared to the acceptable limits in some of the samples. Comparing the present results with the reported results of the different regions of the world, including similar studies at the Bay of Bengal, it can be concluded that the studied region possesses more radioactive elements than the other marine regions. It was also observed that the marine radioactivity of the studied region is gradually increasing, day by day. The results reflect the contribution of technologically enhanced naturally occurring radioactive material (TENORM) pollutants, largely expected to be a result of power generation plants, petroleum, steel, shipbuilding, chemical, pharmaceutical, textile, vegetable oil refineries, glass manufacturing industries, etc. However, the present study indicates that radionuclide intake from the consumption of Bay of Bengal fish and crustaceans still poses an insignificant threat to public health.

Conversely, the metal concentrations of a few trace elements are higher than the acceptable limits in most of the samples, although the studied fish and crustaceans are still safe for human consumption. However, the target cancer risk (TR> $10^{-4}$ ) due to exposure to cadmium, nickel, and chromium indicates that consumer risk persists.

As a whole, the present study indicates an increase in the pollution by radioactivity and trace metals in the marine environment of the Bay of Bengal, mostly derived from an increase in human activities in the region. Therefore, consuming the seafood from the studied region has the potential to cause adverse health impacts if not controlled, and at the same time, all the stakeholders should take proper initiatives to prevent environmental pollution of the Bay of Bengal. The results reported here can be used as baseline data, though the sample size is not large enough. Similar studies should be planned and carried 
out periodically with higher sample sizes to monitor any changes in marine pollution of the Bay of Bengal in the future. Statistical analyses should also be employed in future studies for better understanding of the scenario.

Author Contributions: Conceptualization, K.P.B., A.K.M.S.I.B., S.H.2 and M.B.H.; methodology, S.H.1, N.D., A.K.M.S.I.B. and S.H.2; software, K.P.B., S.H.1 and N.D.; validation, A.K.M.S.I.B., S.C.G., S.H.2 and M.B.H.; formal analysis, K.P.B., S.H.1 and N.D.; investigation, K.P.B., S.H.1, N.D. and A.K.M.S.I.B.; resources, A.K.M.S.I.B. and S.H.2; data curation, K.P.B., S.H.1 and N.D.; writingoriginal draft preparation, K.P.B. and A.K.M.S.I.B.; writing-review and editing, S.H.1, A.K.M.S.I.B. and S.C.G.; visualization, A.K.M.S.I.B. and S.H.2; supervision, A.K.M.S.I.B., S.H.2 and M.B.H.; and project administration, S.H.2 and M.B.H. All authors have read and agreed to the published version of the manuscript.

Funding: This research received no external funding.

Data Availability Statement: The data presented in this study are contained within the article.

Acknowledgments: The authors are thankful to the authority of the Atomic Energy Centre, Chattogram, Bangladesh Atomic Energy Commission, for providing support and technical co-operation to analyze the specimens using the HPGe and AAS. The authors are also delighted to express their gratefulness to the Ministry of Shipping, Peoples' Republic of Bangladesh, for their utmost support. Thanks also goes to Masuda Begum Sampa, Kyushu Institute of Technology, Japan for the fruitful discussion.

Conflicts of Interest: The authors declare no conflict of interest.

\section{References}

1. Ghorab, M.A. Environmental pollution by heavy metals in the aquatic ecosystems of Egypt. Open Access J. Toxicol. 2018, 3, 555603. [CrossRef]

2. Bhuiyan, M.; Ali, M.; Rahman, M. Marine boundary confirmation of Bangladesh: Potentials of sea resources and challenges ahead. Cost Manag. 2015, 43, 18-24.

3. Alam, M.K.; Chakraborty, S.R.; Rahman, A.R.; Deb, A.K.; Kamal, M.; Bhuian, A.S.I. Measurement of radioactivity and hence define the radiological risk associated with the Chittagong city site coastal sediment containing all types of wastes (mills, factories, industries, and municipalities) in Bangladesh. Radiat. Prot. Environ. 2011, 34, 4-8.

4. Rashid, T.; Hoque, S.; Akter, S. Pollution in the bay of Bengal: Impact on marine ecosystem. Open J. Mar. Sci. 2015, 5, 55-63. [CrossRef]

5. Solomon, K. Sources of radioactivity in the ocean environment: From low level waste to nuclear powered submarines. J. Hazard. Mater. 1988, 18, 255-262. [CrossRef]

6. Fazio, F.; Saoca, C.; Ferrantelli, V.; Cammilleri, G.; Capillo, G.; Piccione, G. Relationship between arsenic accumulation in tissues and hematological parameters in mullet caught in Faro Lake: A preliminary study. Environ. Sci. Pollut. Res. 2019, 26, 8821-8827. [CrossRef]

7. Mille, T.; Cresson, P.; Chouvelon, T.; Bustamante, P.; Brach-Papa, C.; Bruzac, S.; Rozuel, E.; Bouchoucha, M.; Tiphaine, M.; Pierre, C.; et al. Trace metal concentrations in the muscle of seven marine species: Comparison between the Gulf of Lions (North-West Mediterranean Sea) and the Bay of Biscay (North-East Atlantic Ocean). Mar. Pollut. Bull. 2018, 135, 9-16. [CrossRef]

8. Fazio, F.; Piccione, G.; Tribulato, K.; Ferrantelli, V.; Giangrosso, G.; Arfuso, F.; Faggio, C. Bioaccumulation of heavy metals in blood and tissue of striped mullet in two italian lakes. J. Aquat. Anim. Health 2014, 26, 278-284. [CrossRef]

9. Cammilleri, G.; Vazzana, M.; Arizza, V.; Giunta, F.; Vella, A.; Dico, G.L.; Giaccone, V.; Giofrè, S.V.; Giangrosso, G.; Cicero, N.; et al. Mercury in fish products: What's the best for consumers between bluefin tuna and yellowfin tuna? Nat. Prod. Res. 2018, 32, 457-462. [CrossRef]

10. Cammilleri, G.; Galluzzo, F.G.; Fazio, F.; Pulvirenti, A.; Vella, A.; Dico, G.M.L.; Macaluso, A.; Ciaccio, G.; Ferrantelli, V. Mercury detection in benthic and pelagic fish collected from Western Sicily (Southern Italy). Animals 2019, 9, 594. [CrossRef]

11. Anandkumar, A.; Nagarajan, R.; Prabakaran, K.; Bing, C.H.; Rajaram, R.; Li, J.; Du, D. Bioaccumulation of trace metals in the coastal Borneo (Malaysia) and health risk assessment. Mar. Pollut. Bull. 2019, 145, 56-66. [CrossRef]

12. Khandaker, M.U.; Asaduzzaman, K.; Nawi, S.M.; Usman, A.R.; Amin, Y.M.; Daar, E.; Bradley, D.A.; Ahmed, H.; Okhunov, A.A. assessment of radiation and heavy metals risk due to the dietary intake of marine fishes (Rastrelliger kanagurta) from the straits of Malacca. PLoS ONE 2015, 10, e0128790. [CrossRef]

13. Kalay, M.; Canli, M. Elimination of essential $(\mathrm{Cu}, \mathrm{Zn})$ and non-essential $(\mathrm{Cd}, \mathrm{Pb})$ metals from tissues of a freshwater fish Tilapia zilli. Turk. J. Zool. 2000, 24, 429-436.

14. Gorur, F.K.; Keser, R.; Akçay, N.; Dizman, S. Radioactivity and heavy metal concentrations of some commercial fish species consumed in the Black Sea Region of Turkey. Chemosphere 2012, 87, 356-361. [CrossRef] [PubMed] 
15. Zalewska, T.; Suplińska, M. Fish pollution with anthropogenic 137Cs in the southern Baltic Sea. Chemosphere 2013, 90, 1760-1766. [CrossRef] [PubMed]

16. Cantillo, A. Comparison of results of Mussel Watch Programs of the United States and France with Worldwide Mussel Watch Studies. Mar. Pollut. Bull. 1998, 36, 712-717. [CrossRef]

17. i Batlle, J.V. Radioactivity in the Marine Environment. In Encyclopedia of Sustainability Science and Technology; Meyers, R.A., Ed.; Springer: New York, NY, USA, 2012; pp. 8387-8425.

18. Elnabris, K.J.; Muzyed, S.K.; El-Ashgar, N.M. Heavy metal concentrations in some commercially important fishes and their contribution to heavy metals exposure in Palestinian people of Gaza Strip (Palestine). J. Assoc. Arab. Univ. Basic Appl. Sci. 2013, 13, 44-51. [CrossRef]

19. Khandaker, M.U.; Heffny, N.; Adillah, B.; Amin, Y.M.; Bradley, D. Elevated concentration of radioactive potassium in edible algae cultivated in Malaysian seas and estimation of ingestion dose to humans. Algal Res. 2019, 38, 101386. [CrossRef]

20. Khandaker, M.U.; Uwatse, O.B.; Khairi, K.A.B.S.; Faruque, M.R.I.; Bradley, D.A. Terrestrial radionuclides in surface (DAM) water and concomitant dose in metropolitan Kuala Lumpur. Radiat. Prot. Dosim. 2019, 185, 343-350. [CrossRef]

21. Doulah, N.-U.; Karim, M.R.; Hossain, S.; Deb, N.; Barua, B.S. Spatial distribution of heavy metals in surface and sub surface sediments of the coastal area of Kutubdia Island, Cox's Bazar, Bangladesh. J. Environ. Anal. Chem. 2017, 4. [CrossRef]

22. Rahman, M.S.; Barua, B.S.; Karim, R.; Kamal, M. Investigation of heavy metals and radionuclide's impact on environment due to the waste products of different iron processing industries in Chittagong, Bangladesh. J. Environ. Prot. 2017, 8, 974-989. [CrossRef]

23. Currie, L.A. Nomenclature in evaluation of analytical methods including detection and quantification capabilities (IUPAC Recommendations 1995). Pure Appl. Chem. 1995, 67, 1699-1724. [CrossRef]

24. Eaton, A.D.; Clesceri, L.S.; Greenberg, A.E.; Franson, M.A.H. Standard Methods for the Examination of Water and Wastewater, 22nd ed.; American Public Health Association APHA: Washington, DC, USA, 2012.

25. Amin, R.M.; Ahmed, F. Estimation of annual effective dose to the adult Egyptian population due to natural radioactive elements in ingestion of spices. Adv. Appl. Sci. Res. 2013, 4, 350-354.

26. ICRP. Dose Coefficents for Intakes of Radionuclides by Workers; Publication 68; ICRP: Ottawa, ON, Canada, 1994.

27. Pulhani, V.; Dafauti, S.; Hegde, A.; Sharma, R.; Mishra, U. Uptake and distribution of natural radioactivity in wheat plants from soil. J. Environ. Radioact. 2005, 79, 331-346. [CrossRef]

28. DoF. Yearbook of Fisheries Statistics of Bangladesh 2017-18; Fisheries Resources Survey System (FRSS), Department of Fisheries, Ministry of Fisheries: Dhaka, Bangladesh , December 2018; Volume 35, p. 86.

29. Aliyu, A.O.; Yakubu, A.; Ajagbe, O.O. Determination of radionuclide concentrations, hazard indices and physiochemical parameters of water, fishes and sediments in River Kaduna, Nigeria. IOSR J. Appl. Chem. 2018, 11, 28-34. [CrossRef]

30. Diab, H.M.; Nouh, S.A.; Hamdy, A.; EL-Fiki, S.A. Evaluation of natural radioactivity in a cultivated area around a fertilizer factory. J. Nucl. Radiat. Phys. 2008, 3, 53-62.

31. Pawel, D.; Leggett, R.W.; Eckerman, K.F.; Nelson, C.B. Uncertainties in Cancer Risk Coefficients for Environmental Exposure to Radionuclides. An Uncertainty Analysis for Risk Coefficients Reported in Federal Guidance Report No. 13; Oak Ridge National Laboratory: Oak Ridge, TN, USA, 2007.

32. Asaduzzaman, K.; Khandaker, M.; Amin, Y.; Mahat, R. Uptake and distribution of natural radioactivity in rice from soil in north and west part of peninsular Malaysia for the estimation of ingestion dose to man. Ann. Nucl. Energy 2015, 76, 85-93. [CrossRef]

33. BBS. Statistical Year Book Bangladesh 2018; BBS: Dhaka, Bangladesh, 2019.

34. Patra, A.C.; Mohapatra, S.; Sahoo, S.K.; Lenka, P.; Dubey, J.S.; Tripathi, R.M.; Puranik, V.D. Age-dependent dose and health risk due to intake of uranium in drinking water from Jaduguda, India. Radiat. Prot. Dosim. 2013, 155, 210-216. [CrossRef]

35. Saha, N.; Mollah, M.; Alam, M.; Rahman, M.S. Seasonal investigation of heavy metals in marine fishes captured from the Bay of Bengal and the implications for human health risk assessment. Food Control 2016, 70, 110-118. [CrossRef]

36. Akoto, O.; Bismark Eshun, F.; Darko, G.; Adei, E. Concentrations and health risk assessments of heavy metals in fish from the Fosu Lagoon. Int. J. Environ. Res. 2014, 8, 403-410.

37. Ahmed, K.; Shaheen, N.; Islam, S.; Mamun, H.; Mohiduzzaman, A.; Bhattacharjee, L. Dietary intake of trace elements from highly consumed cultured fish (Labeo rohita, Pangasius pangasius and Oreochromis mossambicus) and human health risk implications in Bangladesh. Chemosphere 2015, 128, 284-292. [CrossRef]

38. USEPA. In Risk Assessment Guidance for Superfund-Human Health Evaluation Manual (Part A); U.S. Environmental Protection Agency: Washington, DC, USA, 1989; 1, pp. 1-288.

39. Wang, X.; Sato, T.; Xing, B.; Tao, S. Health risks of heavy metals to the general public in Tianjin, China via consumption of vegetables and fish. Sci. Total Environ. 2005, 350, 28-37. [CrossRef] [PubMed]

40. Javed, M.; Usmani, N. Accumulation of heavy metals and human health risk assessment via the consumption of freshwater fish Mastacembelus armatus inhabiting, thermal power plant effluent loaded canal. SpringerPlus 2016, 5, 776. [CrossRef]

41. Zeng, F.; Wei, W.; Li, M.; Huang, R.; Yang, F.; Duan, Y. Heavy metal contamination in rice-producing soils of Hunan Province, China and potential health risks. Int. J. Environ. Res. Public Health 2015, 12, 15584-15593. [CrossRef]

42. Pollution of Karnafully River Water-Causes, Effects and Recommendations. 2003. Available online: https://gspmarinebd.com/ wp-content/uploads/2020/01/River.pdf (accessed on 17 December 2020). 
43. Yasmin, S.; Barua, B.S.; Khandaker, M.U.; Kamal, M.; Rashid, A.; Sani, S.A.; Ahmed, H.; Nikouravan, B.; Bradley, D. The presence of radioactive materials in soil, sand and sediment samples of Potenga sea beach area, Chittagong, Bangladesh: Geological characteristics and environmental implication. Results Phys. 2018, 8, 1268-1274. [CrossRef]

44. IAEA. Sediment Distribution Coefficients and Concentration Factors for Biota in the Marine Environment; Technical Report No. 422; IAEA: Wien, Austria, 2004.

45. Khan, M.F.; Wesley, S.G. Radionuclides in resident and migratory fishes of a wedge bank region: Estimation of dose to human beings, South India. Mar. Pollut. Bull. 2012, 64, 2224-2232. [CrossRef]

46. Sowol, O.; Giwa, K.W. Estimation of annual dose rate of natural radionuclides in man from crabs in River Odeomi Ijebu waterside Ogun State Nigeria. Int. J. Sci. Technol. 2013, 2, 438-441.

47. Alam, M.; Chowdhury, M.; Kamal, M.; Ghose, S. Radioactivity in marine fish of the Bay of Bengal. Appl. Radiat. Isot. 1995, 46, 363-364. [CrossRef]

48. Ghose, S.; Alam, M.; Islam, M. Radiation dose estimation from the analysis of radionuclides in marine fish of the Bay of Bengal. Radiat. Prot. Dosim. 2000, 87, 287-291. [CrossRef]

49. Kabir, M.H.; Miah, M.M.H.; Rahman, M.H.; Kamal, M.; Chowdhury, M.T. Study of the naturally occurring radionuclide concentrations and the estimation of dose rates for the samples collected from the St. Martin's Island, Chittagong, Bangladesh. Materials A 2017, 2, 39-48.

50. Al-Busaidi, M.; Yesudhason, P.; Almughairi, S.; Alrahbi, W.A.K.; Al-Harthy, K.; Al-Mazrooei, N.; Al-Habsi, S. Toxic metals in commercial marine fish in Oman with reference to national and international standards. Chemosphere 2011, 85, 67-73. [CrossRef] [PubMed]

51. Ullah, A.K.M.A.; Maksud, M.; Khan, S.; Lutfa, L.; Quraishi, S.B. Dietary intake of heavy metals from eight highly consumed species of cultured fish and possible human health risk implications in Bangladesh. Toxicol. Rep. 2017, 4, 574-579. [CrossRef] [PubMed]

52. Bashir, F.H.; Othman, M.S.; Mazlan, A.G.; Rahim, S.M.; Simon, K.D. Heavy metal concentration in fishes from the coastal waters of Kapar and Mersing, Malaysia. Turk. J. Fish. Aquat. Sci. 2013, 13, 375-382. [CrossRef]

53. Rosli, M.; Samat, S.; Yasir, M.; Yusof, M. Analysis of heavy metal accumulation in fish at terengganu coastal area, Malaysia. Sains Malays. 2018, 47, 1277-1283. [CrossRef]

54. El-Bahr, S.M.; Abdelghany, A. Heavy metal and trace element contents in edible muscle of three commercial fish species, and assessment of possible risks associated with their human consumption in Saudi Arabia. J. Adv. Vet. Anim. Res. 2015, 2, 271. [CrossRef]

55. Medeiros, R.J.; Dos Santos, L.M.G.; Freire, A.S.; Santelli, R.E.; Braga, A.M.C.; Krauss, T.M.; Jacob, S.D.C. Determination of inorganic trace elements in edible marine fish from Rio de Janeiro State, Brazil. Food Control 2012, 23, 535-541. [CrossRef]

56. Vijayakumar, P.; Lavanya, R.; Veerappan, N.; Balasubramanian, T. Heavy Metal Concentrations in Three Commercial Fish Species in Cuddalore Coast, Tamil Nadu, India. J. Exp. Sci. 2011, 2, 20-23.

57. De, T.K.; De, M.; Das, S.; Ray, R.; Ghosh, P.B. Level of heavy metals in some edible marine fishes of mangrove dominated tropical estuarine areas of Hooghly river, North East Coast of Bay of Bengal, India. Bull. Environ. Contam. Toxicol. 2010, 85, 385-390. [CrossRef]

58. Kumar, B.; Sajwan, K.S.; Mukherjee, D.P. Distribution of heavy metals in valuable coastal fishes from North East Coast of India. Turk. J. Fish. Aquat. Sci. 2012, 12, 81-88. [CrossRef]

59. Sharif, A.; Mustafa, A.; Mirza, A.; Safiullah, S. Trace metals in tropical marine fish from the Bay of Bengal. Sci. Total Environ. 1991, 107, 135-142. [CrossRef]

60. Sharif, A.; Mustafa, A.; Amin, M.; Safiullah, S. Trace element concentrations in tropical marine fish from the Bay of Bengal. Sci. Total Environ. 1993, 138, 223-234. [CrossRef]

61. Khan, A.; Ali, M.; Biaswas, S.; Hadi, D. Trace elements in marine fish from the Bay of Bengal. Sci. Total Environ. 1987, 61, 121-130. [CrossRef] 